\title{
TAGHYDRONUS
}

\author{
conmosworis \\ BOUI KNOER
}

1917 





\title{
MEMOIRS
}

OF THE

Dnay 20.1918

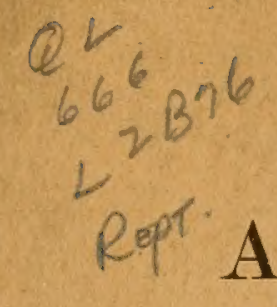

ASIATIC SOCIETY OF BENGAL

VOL. V, No. 6, pp. $207-235$.

\section{A REVISION OF THE LIZARDS OF THE GENUS TACHYDROMUS./}

BY

\author{
G. A. BOULENGER, LL.D., D.So., F.R.S. \\ (Published by Permission of the Trustees of the British Museum)
}

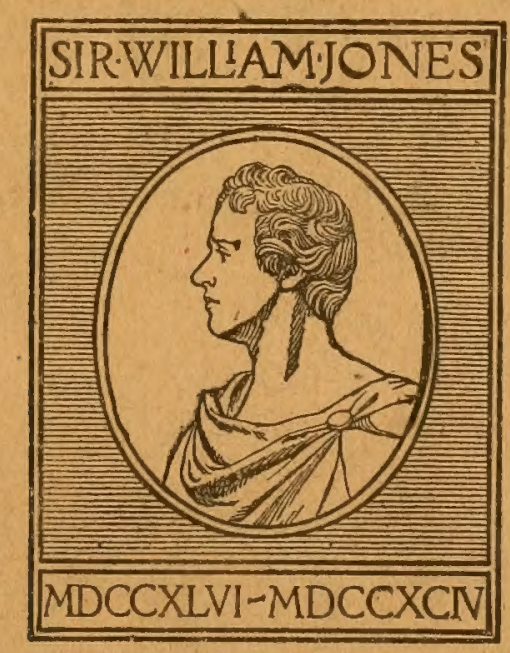

CALCUTTA :

Printed at the Baptist Mission Press, and published by The Astatic Society, 1, Park Strreeit.

1917.

Price Rs. 3 ; or $4 s .6 d$.

$19-11-17$ 
○ 


\title{
A Revision of the Lizards of the Genus Tachydromus.
}

\author{
By G. A. BOUl.ENGER, LI.D., D.Sc., F.R.S. \\ (Published by Permission of the Trustees of the British Museum).
}

[With plates XLVI and XLVII].

\section{INTRODUCTION}

The species of Tachydromus, a genus of Lacertidæ characteristic of the Far East, and the only one of the family to extend eastward of the Bay of Bengal, are much in need of revision. A number have been described since the publication of the third volume of the British Museum Catalogue of Lizards, in which, owing to insufficient material, I united several that have since proved to be perfectly valid. The importance to be attached to various characters, such as the number of rows of plates along the back and belly, of inguinal pores, and of chin-shields, has often been exaggerated and has led to the establishment of species which seem to be untenable. My object in giving very detailed descriptions, with notes on individual variations, accompanied by tabulations of the numerical characters in the extensive material now at my disposal,' is to convey a clearer view of the state of things and thus to enable future workers to form a more correct idea of the value to be attached to these characters. I trust to have succeeded in avoiding the two extremes into which previous authors have fallen, viz. of over-multiplying species and of underrating the importance of certain modifications which may appear trivial at first.

Although generally averse to the multiplication of generic divisions, I feel compelled to propose two new genera for species previously described under Tachydromus, viz. T. dorsalis, Stejneg., and T. kuehnei, Van Denb., the former differing in the more normal dorsal lepidosis, the latter in the form of the digits, unique in the family Lacertidæ.

I have also to offer a suggestion as to the exact relationship of Tachydromus, which has been regarded as occupying a very isolated position in the family to which it belongs. The northen species $T$. amurensis, Peters, shows it to be much nearer to Lacerta than was hitherto believed, as I explain in my comments on that species, which differs so much from $T$. sexlineatus, Daud., the type of the genus, and stands at the other end of the series.

\section{Tachydromus, Daud.}

Tachydromus, ${ }^{2}$ Daud. Hist. Rept. iii, p. 25 I (I802); Wagl. Syst. Amph., p. I57 (I830); Wiegm. Herp. Mex., p. ro (I834); Dum. et Bibr. Ėrp. Gén., v, p. I55 (I839); Gray, Cat. Liz., p 52 (I845); Günth. Rept. Brit. Ind., p. 69 (I864); Lataste, Ann. Mus. Genova (2) ii, I885, p. 125 ; Bouleng. Cat. Liz., iii, p. 3 (I887), and Faun. Ind., Rept., p. I68 (I890).

Tachysaurus, Gray, 1.c. 
Head shields normal.' Nostril pierced between the nasal, one or two postnasals, and the first upper labial. Lower eyelid scaly. Collar more or less distinct or absent. Back with large plate-like subimbricate scales with strong keels forming continuous lines; sides with small juxtaposed or granular scales; ventral plates more or less imbricate, often pointed and keeled. Digits cylindrical or slightly compressed, with smooth or somewhat tubercular lamellæ inferiorly. Femoral pores reduced to one $^{2}$ to three. Tail long or extremely long, cylindrical.

Eastern Asia.

The parietal foramen is constantly present and pterygoid teeth are absent or reduced to 2 to 5 .

The term 'inguinal pores' has been universally used for the one or two pores on each side of the præanal region, as is the rule in this genus, and no exception could be taken to this terminology were it not that when more than two pores are present, the series extends on to the thigh. As the single pore is part of the series known as femoral pores in the other Lacertidæ it is more logical, in view of securing a uniform terminology, to discard the term 'inguinal' and to express the state of things in Tachydromus by saying that the series of femoral pores is reduced to one to three. In several forms of Lacerta and Latastia, when the number of femoral pores falls very low, the reduction takes place from the distal end of the thigh, thus leading to the condition in Tachydromus, as specimens of Lacerta vivipara and Latastia longicaudata with only five femoral pores show very clearly. It is also noteworthy that in the African analogue of Tachydromus, Poromera, Blgr., the series of femoral pores, though a long one, ends at some distance from the knee-joint.

\section{Synopsis OF THE SPECIES.}

I. Head not more than $I_{\frac{3}{4}}$ times as long as broad.

A. 4 supraoculars, first very small (rarely absent); dorsal plates in 5 to 8 longitudinal series, ventrals in 8 or Io.

I. 4 or 5 pairs of chin-shields (very rarely 3 ); ventral plates in 8 longitudinal series, feebly keeled or all except the outer smooth; 29 to 40 plates and scales round middle of body.

Dorsal plates in 7 or 8 longitudinal series; ventral plates in 22 to 28 transverse series ; 3 femoral pores on each side; rostral in contact with frontonasal; tail $I \frac{3}{5}$ to $2 \frac{1}{5}$ times length of head and body

Dorsal plates in 5 to 7 longitudinal series; ventral plates in 22 to 25 transverse series ; 2 (very rarely 3 ) femoral pores on each side; rostral nearly always in 
contact with frontonasal; tail 2 to $3 \frac{1}{3}$ times length of head and body

2. T. tachydromoides,

Schleg.

Dorsal plates in 8 longitudinal series; ventral plates in 27 to 29 transverse series; a single femoral pore on each side; nasals in contact behind rostral . .

2. 3 pairs of chin-shields (very rarely 4 ); ventral plates keeled, often strongly; 33 to 48 plates and scales round middle of body.

Dorsal plates in 5 to 7 (rarely 8) longitudinal series; ventral plates in 8 longitudinal and 20 to 30 (usually 26 to 28 ) transverse series; a single femoral pore on each side

4. T. septentrionalis,

Crthr.

Dorsal plates in 7 or 8 longitudinal series; ventral plates in 8 , more frequently Io, longitudinal and 27 to 33 transverse series; I or 2 femoral pores on each side.

B. 3 supraoculars, first large and in contact with the second loreal; dorsal plates in 4 longitudinal series, ventrals in 12.

Ventral plates in 22 to 25 transverse series; 26 to 28 plates and scales round middle of body; 3 pairs of chin-shields; 2 or 3 femoral pores on each side; tail a little over twice length of head and body

3. T. wolteri, J. G. Fisch.

(1)

5. T. formosanus, Blgr.

6. T. khasiensis, Blgr.

II. Head at least nearly twice as long as broad; ventral plates strongly keeled.

A. Dorsal plates in 7 to Io longitudinal series; ventral plates in 6 or 8 longitudinal and 26 to 31 transverse series; a single femoral pore on each side.

37 to +5 plates and scales round middle of body; 3 pairs of chin-shields, rarely $4 ; 3$ or 4 supraoculars; tail $2 \frac{1}{2}$ to $3 \frac{1}{3}$ times length of head and body .. 28 to 32 plates and scales round middle of body; 4 or 5 pairs of chin-shields ; 4 supraoculars; tail $3 \frac{1}{2}$ to 4 times length of head and body .. .

7. T. smaragdimes, Blgr.

B. Dorsal plates in 4 or 6 longitudinal series, ventrals in Io or I2; 28 to 38 plates and scales round middle of body; 3 supraoculars, third rarely in contact with frontoparietal; I to 3 femoral pores on each side.

Dorsal plates in + (rarely 6) longitudinal series, ventrals

8. T. sauteri, Van Denb. 
in 2 I to 28 transverse series; 3 (rarely 4) pairs of chin-shields; collar more or less distinct; head about twice as long as broad; tail 3 to 5 times length of

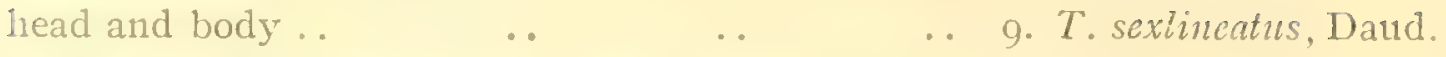

Dorsal plates in 6 longitudinal series, ventrals in 30 transverse series; 4 pairs of chin-shields; no trace of a collar; head $2 \frac{1}{3}$ times as long as broad; tail $2 \frac{2}{5}$ times as long as head and body

‥ IO. T. hanghtonianus,

\section{Tachydromus amurensis.}

Tachydromus amurensis, Peters, Sitzb. Ges. Naturf. Fr. Burl. I88I, p. 7I; Bouleng. Cat. Liz., iii, p. 6 (I887); Günth. An11, and Mag. N.H. (6) i, I888. p. I69; Bouleng. Ann, and IIag. N.H. (6) v, I890, p. I37; Nikolsky, Herp. Ross., p. 92 (I905) ; Stejneg. Herp. Japan, p. 245 ig. (I907).

Body feebly depressed. Head about $I \frac{1}{2}$ times as long as broad, its depth equal to the distance between the anterior corner of the eye and the tympanum, its length $3 \frac{3}{4}$ to 4 times in length to vent in males, $4 \frac{1}{2}$ to $4 \frac{2}{3}$ times in females; snout obtuse, with obtuse canthus, as long as or slightly shorter than the postocular part of the head. Pileus $I_{4}^{\frac{3}{4}}$ to 2 times as long as broad. Neck as broad as the head. Limbs short; the hind limb reaches the elbow or tie axil in males, barely the wrist in females; foot as long as the head or slightly longer. Tail $\frac{3}{5}$ to a little over 2 times the length of head and body.

Nostril pierced between three shields. Rostral not touching the nostril, broadly in contact with the frontonasal, which is broader than long and as broad as the in teruarial space; prefrontals forming a median suture or separated by a small azygous shield; frontal as long as its distance from the end of the snout, $I_{4}^{\frac{1}{4}}$ to $I_{2}^{\frac{1}{2}}$ times as long as broad, of nearly equal width throughout, or narrower behind than in front; parietal a little longer than broad (not more than $I_{4}^{\frac{1}{4}}$ ), in contact with the upper postocular and with 3 or 4 temporals; interparietal a little longer than broad; occipital much shorter than the interparietal, its posterior border usually convex and projecting beyond the parietals. 4 supraoculars, first very small, sometimes divided into two, or in contact with the frontal, second and third equal or second the longer, fourth small but larger: than the first, sometimes not in contact with the frontoparietal; ${ }^{2}$ t, rarely 3 or 5 , superciliaries, first longest, all in contact with the supraculars, or with 2 or 3 granules between them. Nasal forming a suture with the anterior loreal above the small postnasal; posterior loreal longer than the anterior; 4'upper labials * anterior to the subocular, which is narrower beneath than above, sometimes very slightly. Temporal scales small, smooth or feebly keeled; tympanic shield present; one or two enlarged upper temporals often present.

$t$, rarely $5 \%$, pairs of chin-shields, the two or three anterior meeting in the minhle; ig to 24 sulat scales in a straight line between the symphysis of the cinin-

In a male from Chabarovlia.

Which is divided into two in a male from Cluabarovka.

5 In a female from Chabirovki.

\footnotetext{
2 In a female trom Chabarorka,

+5 on one side in a male from Clabarovka.
} 
shields and the median collar-plate, anterior granular and smooth, posterior enlarged, imbricate, smooth or faintly keeled, and merging gradually into the collar, which is composed of 8 to II rounded or obtusely pointed plates, the median smooth, the outer feebly keeled.

Dorsal plates obtusely pointed or rounded behind, in 6 longitudinal series, with I or 2 smaller plates on the median line, or in 8 series in front and 6 behind; sides with one upper and 3 or 4 lower series of keeled scales and a median granular area. Ventral plates in 8 longitudinal and 22 to 28 transverse series, the outer pointed and feebly keeled, the others smooth, broader than long and shaped as in Lacertu viriparu 30 to 40 plates and scales round the middle of the body. Præanal plate large, smooth, entire (males) or longitudinally divided or semidivided (females), bordered by one semicircle of small plates.

Upper surface of limbs with rhombic keeled scales, much smaller than the dorsals. 3 femoral pores on each side.' Subdigital lamellæ single or partly single and partly divided, I9 to 23 under the fourth toe.

Caudal scales strongly keeled, pointed or shortly mucronate, in somewhat longer and shorter whorls alternately, the fourth or fifth of which contains 16 to 20 scales. The scaling of the regenerated tail similar to that of Lacerta vivipara.

Brown or olive-grey above, uniform or with irregular dark brown spots ; sides with a broad dark brown or black band, the upper border of which may show a series of indentations; a dark streak on the canthus rostralis; usually a more or less distinct light, dark-edged streak from the lower eyelid to the shoulder, passing through the lower part of the ear-opening, sometimes continued as a series of spots to the base of the hind limb. Lower parts yellowish or greenish white.

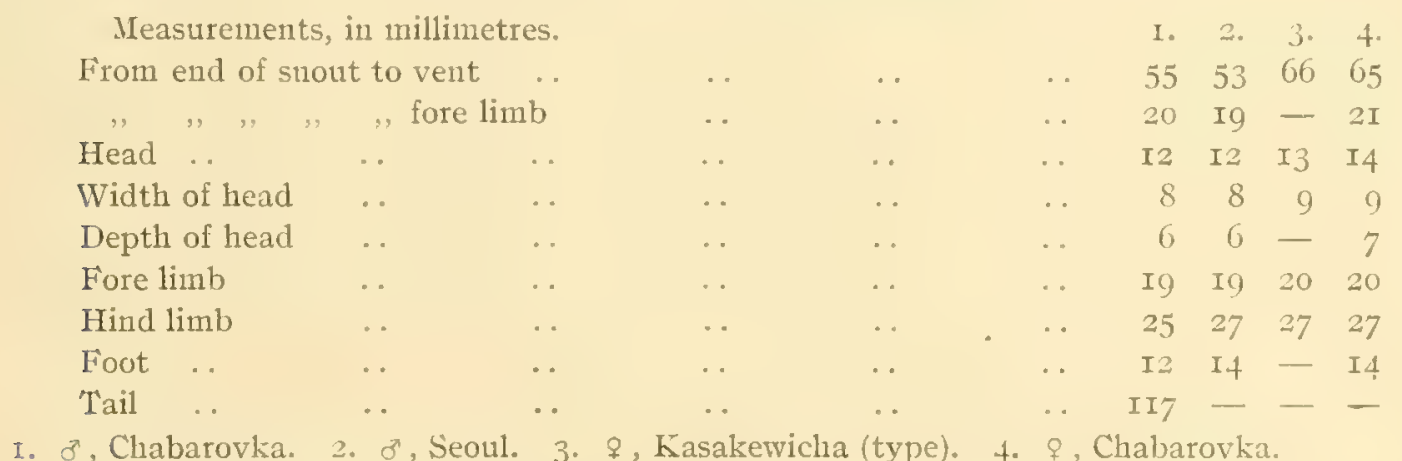

\section{Particulars of specimens examined.}

\begin{tabular}{|c|c|c|c|c|c|c|c|c|c|c|c|}
\hline s. Chabarovka, & Jssuri & . & . & $\begin{array}{c}\text { I. } \\
55\end{array}$ & $\begin{array}{l}2 . \\
35\end{array}$ & $\begin{array}{r}3 . \\
7\end{array}$ & $\begin{array}{l}4 . \\
8\end{array}$ & $\begin{array}{l}5 \\
26\end{array}$ & 6. & $\begin{array}{l}7 . \\
22\end{array}$ & $\begin{array}{l}8 \\
3\end{array}$ \\
\hline, & , & . & . & 54 & 35 & 7 & 8 & 25 & Io & 22 & 3 \\
\hline q, & ," & . & . & 65 & 40 & 8 & 8 & 28 & 9 & 24 & 3 \\
\hline " &. & . & . & 65 & 33 & 7 & 8 & 27 & 9 & I9 & 3 \\
\hline ๙, Seoul, Corea & . & . & . & 53 & 35 & 7 & 8 & 24 & IO & $2 \mathrm{I}$ & 3 \\
\hline o, Corea & . & . & . & 50 & 30 & 8 & 8 & 22 & Io & 22 & 3 \\
\hline
\end{tabular}

A female from Chabarovka shows an ill-defined fourth pore on the right side.

2 In addition to these I have examined the type, a female from Kasakewicha, on the Amoor, preserved in the Berlin Museum 
I. I.ength from snout to vent (in millinetres). 2. Scales and plates round middle of body. 3 . Longitudinal series of dorsal plates and scales. 4. Longitudinal series of ventral plates. 5. Transverse series of rentral plates. 6. Plates in collar. 7. Gular scales in straight median line. 8. Femoral pores m each sitce. 0. I amellar scales under fourth toe.

Habitat. South-Eastern Siberia, Manchuria, Corea.

$T$. ammrensis is the most Lacerta-like species of the genus, and its agreement in many respects with $L$. vivipara' is the more notervorthy for the fact that the latter is the only species of Lacertu which extends eastward to the Pacific Ocean. ${ }^{2}$ The agreenent is not only in the form of the head and the comparatively short tail, but also in the shape and arrangement of the head-shields, especially those bordering the nostril, and the occasional separation of the fourth supraocular from the frontoparietal, and of the ventral shields. As the scaling of the back and the coloration may very well be derived from the condition in $L$. vivipara, I have little doubt that the genus Tachydrom is to be regarded as directly modified from an oriental species of Lacerta connected with $L$. vivipara, if not from that species itself.

\section{Tachydromus tachydromoides, Schleg.}

Lacerta tachydromoides, Schleg. Faun. Japon., Rept., p. Ior, pl. i, figs. 5-7 (IS38).

Tachydromus japonicus, Dum. et I3ibr. Erp. Gén.v, p. I6I (1839); Günth. Rept. IBrit. Ind., 1). (o) (I864); Hilgend. Sitzb. Ges. Nat. Fr. Ber1., I880, p. I I2.

Tachysaurus japonicus, Gray, Cat. Liz., p. 52 (I845).

Tachydromes lachydromoides, part., Bouleng. Cat. I,iz., iii, p. 5 (I8S7).

Tachylromus tachydronoides, Günth Ann. anci Mag. N.H. (6) i, I888, p. I60); Stejneg. Herp. Japan, p. 247, tig. (rgo7).

Tachydromus holsti, Bouleng. P'roc. Zool. Soc., IŚ4, 1). 73.3, pl. xlix, fig. I.

Body feebly depressed. Head $I_{2}^{\frac{1}{2}}$ to $I_{\frac{2}{3}}$ times as long as broad, its depth equal to the distance between the anterior corner of the eye and the tympanum, its lengtl $3 \frac{2}{3}$ to 4 times in length to vent in males, + to $4 \frac{1}{2}$ times in females; snout pointed, with strong canthus and nearly vertical loreal region, as long as the postocular part of the head. Pileus $I_{3}^{\frac{4}{3}}$ to 2 times as long as broad. Neck as broad as the head. The hind limb reaches the axil, the shoulder, or the collar in males, the wrist, the elbow, or the axil in females; foot I to $I_{3}^{1}$ times as long as the head. Tail 2 to $3 \frac{1}{5}$ times the length of head and body ( $I_{3}^{2}$ times in the very young).

Nostril pierced between three shields. Rostral not entering the nostril, nearly always in contact with the frontonasal*, usually broadly; frontonasal as long as broad or slightly broader, as broad as the internarial space or a little broader; prafrontals forming a median suture; ${ }^{6}$ frontal as long as its distance from the end of the suout, $I_{2}^{\frac{1}{2}}$ to 2 times as long as broad, usually narrower behind than in front; parietals as long as broad or a little longer than broad (up to $I_{3}^{1}$ ), interparietal $I_{3}^{1}$ to 2 times as long as broad; occipital small, much shorter than the interparietal, often

\footnotetext{
1 have therefore represented details of that species on plate XI,VI for comparison with $T$. amurcusis.

The Lasternmost specimens slnow, on an average, a lower number of pores (5 to il) than the Western.

1 character which has becone fixed in $T$. senlineatus, at the other end of the series.

+ Two cxceptious, male from Kosluiken and female from Koyosum, in which the nasals meet belinil the rostral.

sometimes s.parated lyy a small azyos shicld, according to Stejueger.
} 
separated from it by the parietals meeting in the middle, sometimes reduced to a granule. 4 supraoculars, first very small, rarely in contact with the frontal, ${ }^{1}$ second and third equal or second the larger, fourth small but larger than the first; 4, rarely 5, superciliaries, first or first and second longest; a complete or, more often, incomplete series of granules between the supraoculars and the superciliaries, exceptionally reduced to 2 or 3 granules. Nasal forming a suture with the anterior loreal, above the small postnasal ; ${ }^{2}$ anterior loreal shorter than the second; 4 upper labials, rarely $3^{3}$, anterior to the subocular, which is narrower beneath than above. Temporal scales small, more or less distinctly keeled; 2 or 3 enlarged upper temporals, the nirst not in contact with the fourth supraocular; tympanic shield present.

4 pairs of chin-shields, the two or three anterior meeting in the middle; I 8 to 25 gular scales, between the symphysis of the chin-shields and the median collar-plate, anterior granular, smooth, posterior enlarged, imbricate, pointed, smooth or more frequently feebly keeled and merging gradually into the collar, which is composed of 9 to 12 pointed, smooth or keeled plates.

Dorsal plates obtusely pointed or rounded behind, in 4 or 6 longitudinal series, with I or 2 series of smaller plates on the median line, making 5 to 7 series altogether; sides with one upper and 3 to 6 lower series of keeled scales and a median granular area. Ventral plates in 8 longitudinal and 22 to 25 transverse series, the outer pointed and keeled, the others also pointed, or rounded or truncate behind, smooth or feebly keeled. 29 to 35 plates and scales round the middle of the body. Præanal plate large, smooth, very rarely longitudinally divided, ${ }^{6}$ bordered by one semicircle of small plates.

Upper surface of limbs with rhombic keeled scales, much smaller than the dorsals. 2, very rarely 3, femoral pores on each side. Subdigital lamellæ mostly divided, 20 to 26 under the fourth toe.

Caudal scales strongly keeled and shortly mucronate, in somewhat longer and shorter whorls alternately, the fourth or fifth of which contains I4 to 20 scales.

Brown or olive above, sometimes greenish on the anterior part of the back, uniform or with small irregularly scattered blackish spots; sometimes a light dorsolateral streak, starting from the superciliary edge; usually a dark brown or blackish lateral band ${ }^{6}$ from behind the eye, sometimes with a few light spots, the upper edge often crenulated; a dark streak on the canthus rostralis; a more or less distinct light or white streak, often black-edged, from the lower eyelid to the shoulder, through the lower part of the ear-opening, sometimes continued as a streak or series of spots to the base of the hind limb. Lower parts white, throat and breast sometimes greenish. 'Tail pale brown or reddish, with a dark lateral streak.

1 Absent on one side in a female (Lataste collection).

2 The postnasal is absent and the first loreal transversely divided into two in a female from Tokyo.

33 on both sides in a female from Tsu Shima, on one side in a female from Takanori.

+ One exception with 3 and one with 5 out of 66 specimens examined by Stejneger. 3 on one side and 4 on the other in the type of $T$. holsti.

5 Female from Nagasali.

6 This band is totally absent in the types (female and young) of $T$. holsti, as well as in a female from Nagasaki. 
Measurenents, in millinetres.

lirom end of snout to vent

.. fore limb

Head .

IVidth of head

Depth of head

liore limb

Hind limb

Foot

Tail

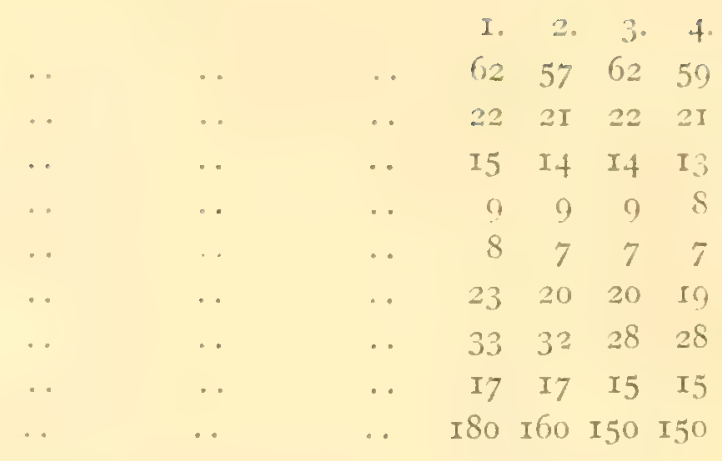

1. 3, Nagasaki. 2. o, Kochi Keu. 3. \%, Japan (Lataste Coll.). 4. 9, Myianoshita.

\section{Particulars of specimens examined.}

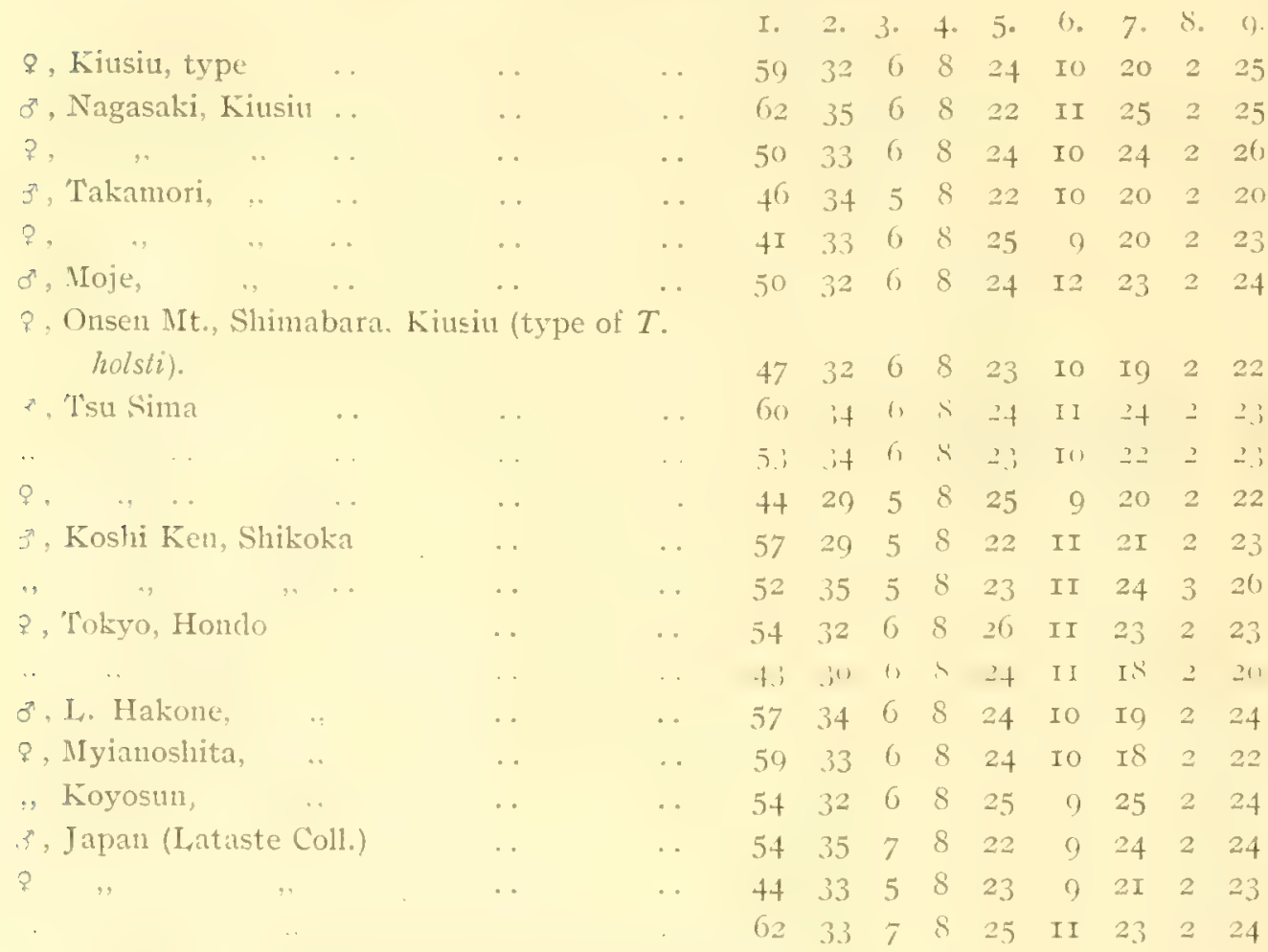

Explanation of table same as for the preceding species, p. 2 I2.

Habitat. Japan, from Yezo to Kiusiu and Tsu Sima.

This species is very closely allied to the preceding, differing in the more pointed snout with stronger cauthus, 5 to 7 longitudinal series of dorsal plates instead of 7 or 8 , and nearly constantly 2 femoral pores instead of 3 .

\section{Tachydromus wolteri, J. G. Fisch.}

Tachydromus zolleri, J. G. IYischer, Jahrb. Hamb. Wiss. Anst., ii, I885, p. 82; Günth. Ann. and IIag. N.H. (6) i, I888, p. I69; Stejneg. Herp. Japan, p. 247 (I907).

Tachydromus tachydromoides, part., Bouleng. Cat. Liz., iii, p. 5 (I887).

Body feebly depressed. Head $I \frac{3}{5}$ to $I_{3}^{2}$ times as long as broad, its depth equal to the distance between the anterior corner of the eye and the tympanum, its length 
+ times in length to vent; snout pointed, with strong canthus and nearly vertical loreal region, as long as the postocular part of the head. Pileus $I_{5}^{4}$ to 2 times as long as broad. Neck as broad as the head or a little narrower. The hind limb reaches the elbow; foot as long as the head or slightly longer

Nostril pierced between three shields. Rostral not entering the nostril ; nasals forming a very short suture behind the rostral; frontonasal broader than long, as broad as the internarial space; a small shield often present between the præfrontals; frontal as long as its distance from the end of the snout, $I \frac{1}{2}$ to $I_{3}^{2}$ times as long as broad, of nearly equal width throughout; parietals $\mathrm{I} \frac{1}{3}$ times as long as broad; interparietal $I \frac{1}{3}$ to 2 times as long as broad; occipital small, much shorter than the interparietal. 4 supraoculars, first very small, second and third equal, fourth small but larger than the first and rarely in contact with the frontoparietal; ${ }^{2} 4$ or 5 superciliaries, first longest, separated from the supraoculars by a complete series of granules. Nasal forming a suture with the anterior loreal, above the small postnasal; anterior loreal shorter than second; 3 to 5 upper labials ${ }^{3}$ anterior to the subocular, which is narrowed beneath than above. Temporal scales small, keeled; 3 enlarged upper temporals ; tympanic shield present.

4 pairs of chin-shields, the 3 anterior meeting in the middle; $2+$ to 26 gular scales between the symphysis of the chin-shields and the median collar-plate, anterior granular, smooth, posterior enlarged, imbricate, pointed, and keeled, merging gradually into the collar, which is composed of Io to I2 pointed, more or less distinctly keeled plates.

Dorsal plates rounded behind, in 8 longitudinal series, those of the two median series smaller; sides with a more or less distinct upper and 3 or 4 lower series of keeled scales and a median granular area. Ventral plates in 8 longitudinal and 27 to 29 transverse series, the outer pointed and keeled, the others rounded or truncate behind and smooth. 36 to 38 plates and scales round the middle of the body. Præanal plate large, smooth, bordered by one semicircle of small plates.

Upper surface of limbs with rhombic keeled scales, much smaller than the dorsals. A single femoral pore on each side. Subdigital lamellæ mostly divided, Ig to 22 under the fourth toe.

Caudal scales strongly keeled and shortly mucronate, equal or in somewhat longer and shorter whorls alternately, the fourth or fifth of which contains 18 to 20 scales.

Olive above, with a more or less distinct light dorso-lateral streak and a dark olive lateral band; a white, black-edged lateral streak from the loreal region through the lower part of the ear-opening to the base of the hind limb; a dark streak along each side of the tail. Lower parts yellowish or greenish white.

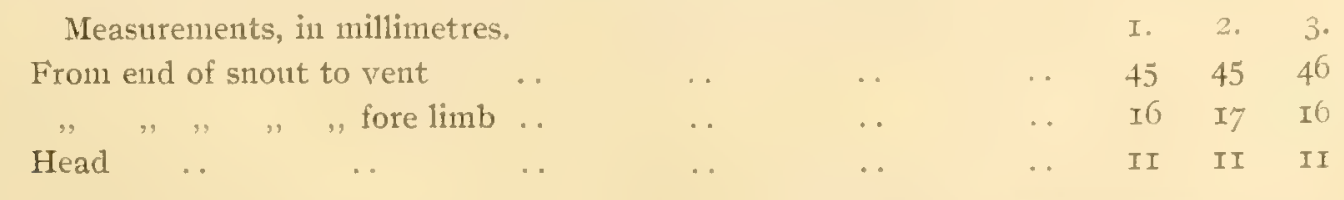




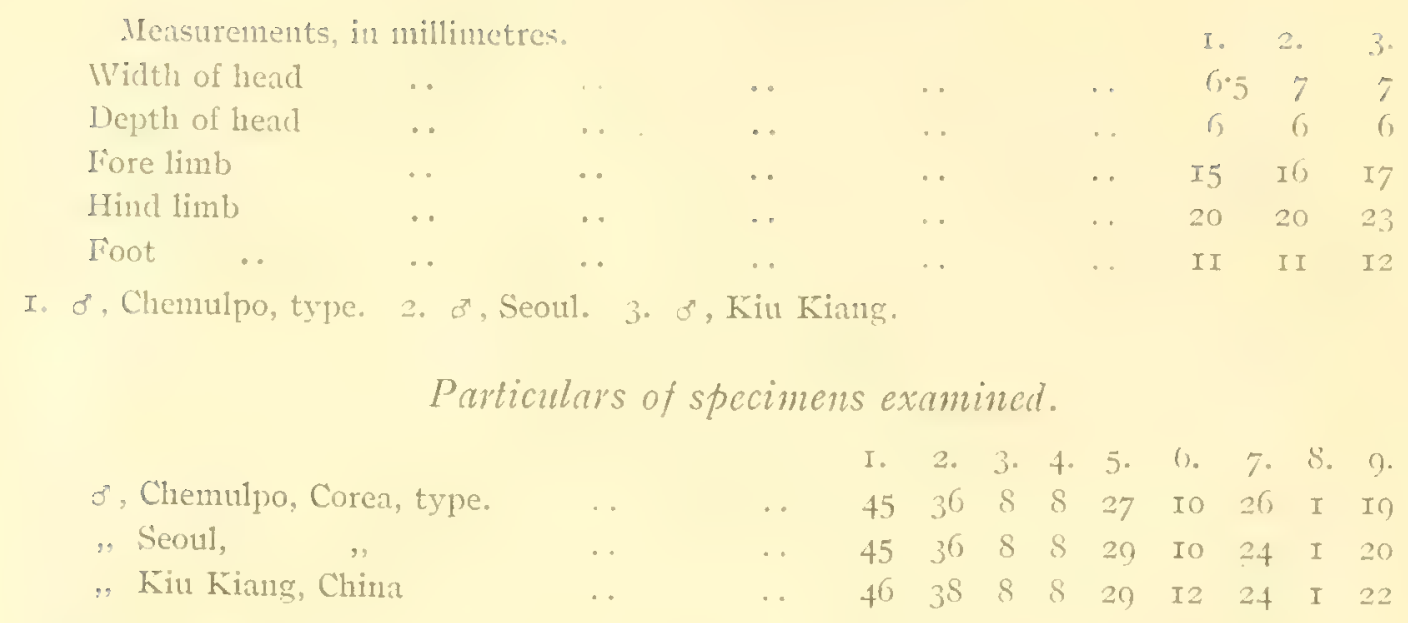

Table as on p.212.

Habitat. Corea and China (Kin Kiang).

Closely allied to $T$. tachydromoides. Differs in having 8 longitudinal series of dorsal plates, 27 to 29 transverse series of ventral plates, instead of 22 to 24 , in males, and a single femoral pore.

\section{Tachydromus septentrionalis, Gthr.}

Tachydromes septentrionalis, Günth. Rept. Brit. Ind., p.70, pl. viii, fig. E..' (I86.t), and Ann. and IIag. N.H. (6) i. I888, p. I66; Boettg. Ber. Senck. Ges. I894, pp. I39, I 45 ; Bouleng. Proc. Zool. Soc., I899, p. I6I, fig.; Werner, Abl. Bayer. Ak. 2, xxii, I903. p. 354; Tan Denb. Proc. Calif. Ac. (4) iii, I9I2, p. 242.

Tachydromes tachydromoides, part., Bouleng. Cat. Liz. iii, p. 5 (I887).

Takydramus scplentrionalis, part., Stejneg. Herp. Japan. p. 232 (1907).

Body not or but slightly depressed. Head feebly convex or even quite flat above, $I \frac{1}{2}$ to $I \frac{3}{4}$ times as long as broad, its depth equal to the distance between the anterior corner or the centre of the eye and the tympanum, its length $3 \frac{2}{3}$ to $4 \frac{1}{5}$ times in length to vent in males, 4 to $4 \frac{1}{2}$ times in females; snout pointed, with strong canthus and nearly vertical loreal region, as long as the postocular part of the head. Pileus 2 to $2 \frac{1}{5}$ times as long as broad. Neck narrower than the head. The hind limb reaches the wrist, the elbow, or the axil in females, the axil or the shoulder in males; foot $I$ to $\mathrm{I}_{3}^{\frac{1}{3}}$ times as long as the head. Tail $2 \frac{1}{3}$ to $3^{\frac{1}{3}}$ times as long as head and body.

Nostril pierced between 3, rarely 4, shields. Rostral not entering the nostril, often narrowly in contact with the frontonasal, ${ }^{2}$ which is as long as broad or slightly broader than long, as broad as or a little broader than the internarial space: præfrontals forming a median suture; frontal as long as its distance from the end of the snout or a little shorter, $I_{2}^{\frac{1}{2}}$ to $I_{3}^{2}$ times as long as broad, usually narrower behind than in front; parietals $I_{3}^{1}$ to $I_{3}^{2}$ times as long as broad; interparietal $I_{3}^{\frac{1}{3}}$ to 2 times

\footnotetext{
I The male type specinen figured is represented with an iutact tail, wlich is not the case, as may be seen from Güther's description. The tail has been inagined by the artist. Sncl restorations were often resorted to in those days, and liave given rise to mucl confusion, as in the case of Chitra indica in the same work.

2 In 15 specinens out of 39 examined by me; in 8 out of 12 examined by Van Denburgh.
} 
as long as broad; occipita! small, much shorter than the interparietal, rarely nearly as large, often separated from it by one or two small shields or by the parietals meeting in the middle. 4 supraoculars, first very small and rarely broken up into 2 or 3 granules, or in contact with the frontal, ${ }^{\prime}$ or absent, ${ }^{2}$ second and third equal or second the longer, fourth small but larger than first and rarely broken up into 2 or $3 ; 4$ or 5 superciliaries, first or first and second largest and usually in contact with the supraoculars; a series of granules, rarely complete, between the supraoculars and the superciliaries. Nasal forming a suture with the anterior loreal above the postnasal, ${ }^{3}$ often forming a very short suture with its fellow behind the rostral; anterior loreal shorter than the second, sometimes divided into two ${ }^{+}$and forming a triangle with the postnasal; ${ }^{5}$ usually 4 upper labials, sometimes 3 or 5 , $^{6}$ anterior to the subocular, which is usually narrower beneath than above. Temporal scales small, more or less distinctly keeled; I, 2, or 3 enlarged upper temporals, the first not in contact with the fourth supraocular; tympanic shield present, narrow and elongate.

3 pairs of chin-shields, ${ }^{7}$ the first or first and second meeting in the middle; 20 to 30 gular scales between the symphysis of the chin-shields and the median collarplate, anterior granular and smooth, posterior enlarged, imbricate, pointed and keeled, and merging gradually into the collar, which is composed of 8 to 12 pointed, keeled plates.

Dorsal plates obtusely pointed or rounded behind, in 4 longitudinal series, with I or 2 series of smaller plates on the median line, and rarely ${ }^{8}$ with an additional series of smaller plates between the two outer series, making 5 to 8 altogether in the middle of the body; often 6,7 , or 8 in front and 4 or 5 behind; 2 to 4 series of keeled scales near the ventral plates, separated from the dorsals by a granular area. Ventral plates in 8 longitudinal and 24 to 30 (usually 26 to 28 ) transverse series, obtusely pointed, more or less strongly keeled, and shortly mucronate. 34 to 48 plates and scales round the middle of the body (usually 35 to 40). Præanal plate moderately large or rather small, smooth, rarely feebly bicarinate and longitudinally bisected, ${ }^{9}$ often not broader than long, with smaller, usually keeled plates in front and on the sides.

Upper surface of limbs with rhombic keeled scales and granules. A single femoral pore on each side. Subdigital lamellæ partly single and partly divided, mostly divided, 23 to 29 under the fourth toe.

I In a male from Kin Kiang.

2 In a female from Kiu Kiang and in a young from Da-zel Valley, Chikiang.

3 Unless its posterior part be severed to form a second postnasal, as in a female from Kiu Kiang.

+ In 4 specimens from Kiu Kiang, in one from Da-zel Valley, and in one from Kuatun.

5 As in Lacerta agilis. - In a male from Kin Kiang, the postnasal forms a suture with the second loreal, below the anterior.

6 3 on both sides in a female from Kiu Kiang, on one side in a female from Chusan and in a young from Che Ǐing near Chusan; 5 on both sides in a nuale from Kuatun and in a female from Ningpo; on one side in two males from Kin Kiang and iu a female from Shanghai.

73 on one side and 4 on the oller in two specinens from Kiu Kiang aud in another from Iñatn1. A sinilar example of asymmetry las been recorded by Werner.

s Male and female from Iruatun, female from Shanghai. 
Caudal scales strongly keeled and shortly mucronate, the keels forming 4 very strong ridges on the upper surface of the basal part of the tail, the whorls nearly equal in length, the fourth or fifth containing I4 to I 8 scales.

Olive, brown, or coppery red on the back, olive, green, or blue on the sides, usually with a light greenish, often black-edged dorsolateral streak, starting from the superciliary edge; a more or less distinct dark canthal streak and a dark band on the temple and side of neck, or continued along the body, sometimes with blue spots, edged below, but no further than the shoulder, by a light streak starting from the lower eyelid. Lower parts yellow, often greenish on the sides.

Measurements, in millimetres.

From end of snout to vent

$\begin{array}{lll}\text { Head . . . } & \ldots \text { fore limb } \\ \text { Width of head } & \ldots & \ldots \\ \text { Depth of head } & \ldots & \ldots \\ \text { Fore limb } & \ldots & \ldots \\ \text { Hind limb } & \ldots & \ldots \\ \text { Foot . } & \ldots & \ldots \\ \text { Tail . } & \ldots & \ldots\end{array}$

$\begin{array}{rrrrrr} & & \text { I. } & 2 . & 3 & 4 . \\ \ldots & \ldots & 75 & 69 & 67 & 65 \\ \cdots & \ldots & 26 & 27 & 24 & 25 \\ \ldots & \ldots & I 8 & 17 & 16 & 16 \\ \ldots & \ldots & I I & I I & 10 & 10 \\ \ldots & \ldots & I 0 & 10 & 8 & 8 \\ \ldots & & 27 & 27 & 23 & 24 \\ \ldots & \ldots & 37 & 36 & 32 & 32 \\ \ldots & \ldots & I 9 & 19 & 17 & 17 \\ \ldots & \ldots & - & 245 & 205 & 155\end{array}$

I. o, Niugpo, type. 3. $\sigma^{\circ}$. Kuatun. 3. ㅇ Kuatun. 4. \&, Kiu Kiang.

\section{Particulars of specimens examined.}

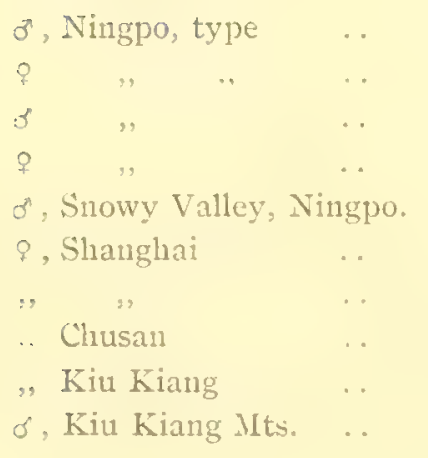

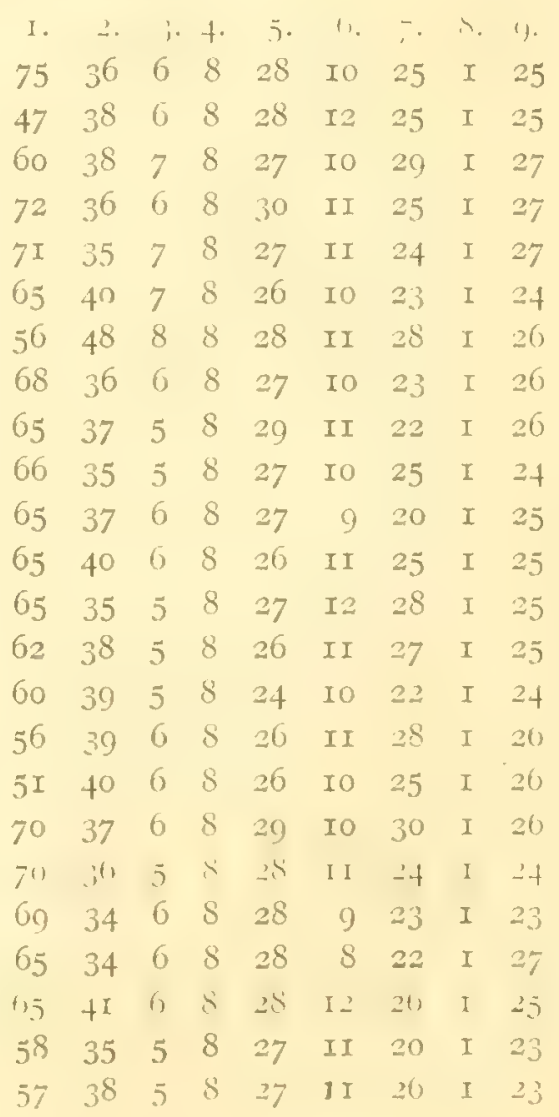




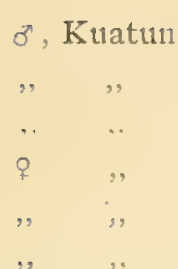

I. 2. 3. 4. 5. 6. 7. 8. 9 .

$\begin{array}{lllllllll}69 & 35 & 5 & 8 & 26 & \text { II } & 22 & \text { I } & 26\end{array}$

$\begin{array}{lllllllll}69 & 38 & 6 & 8 & 28 & 12 & 24 & \text { I } & 25\end{array}$

(6) $3(1) \quad 6 \quad 8 \quad 27$ III 25 I 20

$\begin{array}{lllllllll}70 & 38 & 6 & 8 & 28 & \text { II } & 26 & \text { I } & 28\end{array}$

$\begin{array}{lllllllll}67 & 38 & 8 & 8 & 28 & \text { II } & 23 & \text { I } & 25\end{array}$

$\begin{array}{lllllllll}67 & 44 & 8 & 8 & 28 & \text { I0 } & 25 & \text { I } & 26\end{array}$

Table as on p. $2 \mathrm{I} 2$.

Habitat. China along the Yang-tse-Kiang, north-west to the Province of Kansu, south-east to Fokien.

With an insufficient material, in I887, I unfortunately united this species with $T$. tachydromoides, from which it is perfectly distinct, differing chiefly in the number of chin-shields and of femoral pores, as well as in the constantly keeled ventral plates. The first two characters are not known to suffer any exceptions in the two species here compared, although large series have been examined by me and by others; and this is very remarkable considering that the number of chin-shields certainly varies in $T$. smaragdimus and $T$. sexlineatus, as observed by Van Denburgh, by Stoliczka, and by Annandale, whilst specimens with either one or two femoral pores occur in $T$. formosanus and $T$. sexlineatus.

\section{Tachydromus formosanus, Blgr.}

Tachydromus formosamus, Bouleng. Ann. and Mag. N.H. (6) xiv, I894, p. 462; Stejneg. Herp. Japan, p. 235 (I907); Van Denb. Proc. Calif. Ac. (4) iii, I9I2, p. 245.

Takydromus septentrionalis, part., Stejneg. op. cit., p. 232.

Takydromus stejnegeri, Van Denb. t.c., p. 243.

Body not or but slightly depressed. Head feebly convex, I $\frac{3}{5}$ to $I_{4}^{3}$ times as long as broad, its depth equal to the distance between the anterior corner or the centre of the eye and the tympanum, its length $3 \frac{2}{3}$ to + times in length to vent in males, t to $4 \frac{1}{4}$ times in females; snout pointed, with strong canthus and nearly vertical loreal region, as long as the postocular part of the head. Pileus 2 to $2 \frac{1}{5}$ times as long as broad. Neck narrower than the head. The hind limb reaches the elbow in females, the axil or the shoulder in males; foot $I$ to $I \frac{1}{5}$ times as long as the head. Tail 2 to $3 \frac{3}{5}$ times as long as head and body.

Nostril pierced between 3 shields. Rostral not entering the nostril, rarely in contact with the frontonasal,' which is as long as broad or a little broader, or longer than broad and in contact with the frontal; ${ }^{2}$ profrontals usually forming a median suture, or separated by an azygos shield; frontal as long as its distance from the end of the snout, $I \frac{1}{2}$ to $I_{\frac{3}{4}}$ times as long as broad, a little narrower behind than in front; parietals $I \frac{1}{4}$ to $I \frac{1}{2}$ times as long as broad; interparietal $I \frac{1}{3}$ to 2 times as long as broad; occipital small, much shorter than the interparietal, often separated from it by the parietals meeting in the middle. 4 supraoculars, first very small,

In 27 specimens out of 283 examiued by Van Denburgh (about Io p.c.).

In a male from Taipeh and in another from Punkibo.

3 In a female from Punkiho. 
rarely absent, second and third equal or second the longer, fourth small but larger than first; 4 or 5 superciliaries, first or first and second longest, first in contact with the supraoculars, ${ }^{2}$ followed by a series of granules, or series of granules complete. Nasal forming a suture with the anterior loreal, above the postnasal, usually forming a short suture with its fellow behind the rostral; anterior loreal shorter than the second ; usually + upper labials, rarely $3,{ }^{3}$ anterior to the subocular, which is narrower beneath than above. Temporal scales small, obtusely keeled; a large anterior upper temporal, not in contact with the fourth supraocular, usually followed by one or two smaller shields; tympanic shield present, narrow and elongate.

3 pairs of chin-shields, the first or first and second meeting in the middle; 20 to 29 gular scales between the symphysis of the chin-shields and the median collar-plate, anterior granular and smooth, posterior enlarged, imbricate, pointed and keeled, merging gradually into the collar, which is composed of ro to I2 pointed, keeled plates; no gular fold.

Dorsal plates obtusely pointed or rounded behind, in 6 longitudinal series, usually with I or 2 series of smaller plates on the median line, making 6 to 8 altogether in the middle of the body; usually 8 or Io in front and 6 or 7 behind ; 2 or 3 series of keeled scales near the ventral plates, separated from the dorsals by a granular area. Ventral plates in 8, or more frequently in Io,${ }^{5}$ longitudinal and 27 to 33 transverse series, nbtusely pointed, strongly keeled, and shortly mucronate. 33 to 38 plates and scales round the middle of the body. Pranal plate moderately broad, sometimes not broader than long, smooth or feebly bicarinate, rarely longitudinally bisected, , with smaller keeled plates in front and on the sides.

Upper surface of limbs with rhombic keeled scales and granules. One or two femoral pores on each side. ${ }^{7} \quad 2+$ to 29 lamellar scales under the fourth toe.

Caudal scales strongly keeled and shortly mucronate, the keels forming + very strong ridges on the upper surface of the basal part of the tail, the whorls nearly equal in length, the fourth or fifth containing I4 to I 8 scales.

Brownish olive above, sometimes with darker spots which may form lines along the keels of the dorsal plates; olten a yellowish or greenish white dorso-lateral streak, starting from the superciliary edge; a dark streak from the nostril to the eye, and a dark band on the temple and on the side of the neck, often continued on the body, where it may be spotted with greenish white, a light streak from the lower eyelid,

4 specincus present this exception, according to Van Denburgh.

'lihe rule in $T$. stejngeri of Van Denburg; in 9 specimens examined by him the series of gramules between the supraoculars and the superciliaries is complete, as is the rule in the typical $T$. formosanus,

3 on each side in a male from Punkilio and in a female from Fanshirei.

+4 shields on one side in two specineus examined by Van Denlurgh.

Tau Denburgh says the ventrals are in 8 rows, not reckoning as such the adjacent plates which are often quite as long and must be regarded as ventrals.

In one of the types from C. Formosa.- lwo keeled plates in 3 specimens and two smooth plates in one of $T$. stojnegeri, two kecled plates in + specimens and two smootln plates in 2 of $T$. formosanus (out of 178 ), according to Vian l)enburgls.

7 Van Denburgh found a pores on one sicle in one specimen referred by linu to $T$. stejncgeri; the specimens with a single pore (with 9 exceptions out of $2 S_{4}$ specineus) are regarded as typical $T$. formosanus. 
through the lower part of the ear-opening, to the shoulder, sometimes continued on the side of the body. A black streak on the hinder side of the thigh. Lower parts yellowish or greenish white.

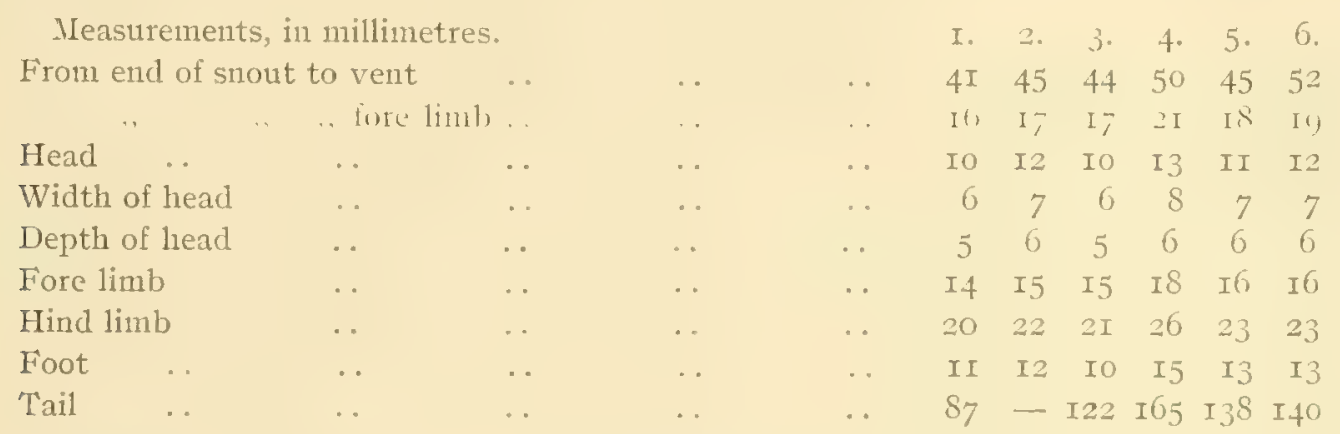

I. + , Taiwanfoo, type. 2. 37, C. Formosa, type. 3. \&, C. Formosa, type. 4. of, Taipeh, cotype of T. stejnegeri. 5. o, Punkiho. 6. क, Kanshirei.

\section{Particulars of specimens examined.}

q, Taiwanfoo, type ..

$\sigma$, Central Formosa, type

?

,

" , Taipeh, co-type of $\bar{T}$. stejnegeri.

, 'Tainan,

, Punkiho

?,

, Kanshirei 1

.. '’amsıi
I. 2. 3. 4. 5. 6. 7. 8. 9.

$\begin{array}{lllllllll}4 \mathrm{I} & 36 & 8 & \text { IO } & 32 & \text { IO } & 23 & 2 & 24\end{array}$

$\begin{array}{lllllllll}45 & 35 & 7 & 8 & 29 & 12 & 22 & 2 & 25\end{array}$

(1) 3(1) 7 I1) (i) I0 $24 \quad 2 \quad-4$

Ht iT is II iI II $24 \geq 2+$

fI i i 7 Il, ; I I $20=21$

$\begin{array}{lllllllll}50 & 34 & 6 & 8 & 28 & \text { II } & 26 & \text { I } & 29\end{array}$

$47 \quad 36 \quad 7$ IO 29 II 26 I 26

45357 I0 27 II 20 I 25

i2 it 7 IO 22 I $2 \quad 25$ I 25

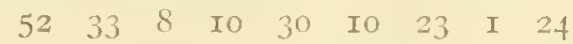

Ht it 4 is in IL 25 I 4

Table as on p. 212.

Habitat. Formosa and Pascadores Islands.

$T$. formosamus is very closely allied to $T$. septentrionalis, differing in the presence of 6 series of large plates along the back instead of 4 , and by the frequent presence of Io series of ventral plates instead of 8 . The size is smaller and the green colour is absent from the sides. I am convinced that Van Denburgh's proposal to separate this species into two, one with normally two femoral pores ( $T$. formosanus), the other with one ( $T$. stejnegeri) is untenable, the general agreement being too great and the supposed-distinctive characters too slight and too inconstant to justify such a course.

\section{Tachydromus khasiensis, sp.n.}

Tachydromus sexlincatus, part., Bouleng. Cat. Liz. iii, p. 4 (I887), and Faun. Ind., Rept., p. I60 (I890); Günth. Ann. and Mag. N.H. (6) i, I888, p. I67.

Body scarcely depressed. Head abont $I_{\frac{3}{4}}$ times as long as broad, its depth equal to the distance between the centre of the eye and the tympanum, its length

I This specimen was received from the Museum of the California Academy under the name of $T$. stejnegeri. Yet in his description Van Denburgh refers all the specimens trom Kanshurei to $T$. formosanus, thus showing the uncertainty in distinguishing the two supposed species. The author rightly observed that unfortunately no one of the distinctive characters is absolutely constant in all specimens. 
4 to $4 \frac{1}{3}$ times in length to vent in males, $4 \frac{1}{2}$ to 5 times in females; snout pointed, with sharp canthus and nearly vertical loreal region, as long as the postocular part of the head. Pileus twice as long as broad. Neck narrower than the head. Hind limb reaching the wrist in females, the elbow in males; foot as long as the head. Tail a little over twice the length of head and body.

Nostril pierced between 3 to 5 shields. Rostral usually entering the nostril; upper head shields rugose; frontonasal broader than long, not or but slightly broader than the internarial space; præfrontals forming an extensive suture; frontal as long as or shorter than its distance from the end of the snout, $I \frac{1}{2}$ to $I_{\frac{2}{3}}$ times as long as broad, of subequal width throughout or a little narrower behind than in front; parietals $I \frac{1}{3}$ to $I_{3}^{2}$ times as long as broad; interparietal $I \frac{1}{3}$ to 2 times as long as broad, much longer than the occipital, which may be broader. 3 supraoculars, first longer than the second and usually in contact with the second loreal ; 3 superciliaries, second longest; no granules between the supraoculars and the superciliaries. Nasal forming a suture with its fellow behind the rostral and with the anterior loreal above the postnasal, which may be very small or absent, in which case the loreal borders the nostril; anterior loreal shorter than the second; 3 or 4 upper labials ' anterior to the subocular, which is not or but little narrower beneath than above. Temporal scales moderately large or rather small, hexagonal, keeled; I, 2, or 3 large upper temporals, first sometimes in contact with the fourth supraocular; a long and narrow tympanic shield.

3 pairs of chin-shields, first and second in contact in the middle. I7 to 22 gular scales in the median line, anterior narrow, juxtaposed, smooth or faintly keeled, posterior increasing in size, imbricate, keeled, and merging gradually into the collar, the plates of which are very distinct, pointed, keeled, and IO or I I in number.

Dorsal plates truncate or shortly mucronate behind, in 6 or 8 longitudinal series on the neck, in 4 on the body. Ventral plates obtusely pointed or shortiy mucronate, strongly keeled, in I 2 longitudinal and 22 to 25 transverse series. Sides with one upper and one lower series of smaller keeled scales and a median granular area. 26 to 28 plates and scales round the middle of the body. Pranal plate rather large, smooth or feebly bicarinate, bordered by a semicircle of small keeled plates.

Upper surface of limbs with rhombic keeled scales. 2 or 3 femoral pores on each side. Subdigital lamellæ single, I9 or 20 under the fourth toe.

Caudal scales strongly keeled and mucronate, the keels forming 4 very strong ridges on the upper surface of the basal part of the tail; the whorls nearly equal in length, the fourth or fifth containing I 4 or 16 scales.

Olive above, with a yellowish or greenish white, usually black-edged dorso-lateral streak starting from the superciliary edge; a dark lateral band from the nostril, through the eye and involving the upper half of the ear-opening, to the tail, edged below by a light streak. Lower parts greenish white (in spirit). Tail reddish in the young. 
Measurements, in millimetres.

From end of snout to vent

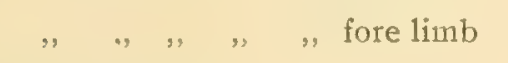

Head

Width of head ..

Depth of head ..

Fore limb

Hind limb

Foot

Tail

\begin{tabular}{|c|c|c|c|c|c|}
\hline & & & & $\sigma^{\pi}$ & $q$ \\
\hline . & . & .. & . & 48 & $5 I$ \\
\hline . & . & . & . & I9 & I7 \\
\hline . & .. & $\ldots$ & . & II & 10.5 \\
\hline . & .. & .. & . & 6.5 & 6 \\
\hline . & $\ldots$ & . & $\ldots$ & 5 & 5 \\
\hline . & . & . & . & I6 & I5 \\
\hline . & . & . & . & 20 & $2 \mathbf{I}$ \\
\hline . & . & . & . & II & II \\
\hline & . & $\ldots$ & . & - & 108 \\
\hline
\end{tabular}

Particulars of specimens examined.

\begin{tabular}{|c|c|c|c|c|c|c|c|c|c|c|c|}
\hline$\pi$ & 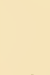 & & & I. & 2. & 3. & 4. & $\begin{array}{l}5 . \\
24\end{array}$ & & $\begin{array}{l}7 . \\
2 \mathrm{I}\end{array}$ & 8. \\
\hline 0 & $\cdots$ & . & . & 48 & 26 & $\begin{array}{l}4 \\
4\end{array}$ & I 2 & 24 & IO & I9 & $\begin{array}{l}3-4 \\
3\end{array}$ \\
\hline , & .. & . & . & 44 & 26 & 4 & I2 & 22 & II & I 8 & 2 \\
\hline$q$ & .. & $\ldots$ & .. & 53 & 28 & 4 & I2 & 23 & Io & 22 & 2 \\
\hline , & . & $\ldots$ & $\ldots$ & $5 \mathrm{I}$ & 25 & + & $\mathrm{I} 2$ & 25 & Io & $2 \mathrm{I}$ & 2 \\
\hline
\end{tabular}

Table as on p. 212.

Habitat. Khasi hills, near Assam. Six specimens, from the collection of Dr. T. C. Jerdon, are preserved in the British Museum. Jerdon referred them to T. sexlineatus (Proc. As. Soc. Beng. I870, p. 72 ).

This species may be regarded as intermediate between $T$. tachydromoides and $T$. sexlineatus, as observed by Günther in I888: "Specimens of $T$. sexlineatus from Khassya, in the British Museum, have on the whole a somewhat shorter and less tapering snout, also shorter toes than the typical form, and approach in these respects $T$. meridionalis."

\section{Tachydromus smaragdinus, Blgr.}

Tachydromus smaragdinus, Bouleng. Proc. Zool. Soc. I887, p. I47, pl. xvii, fig. 2, and pl. xviii, fig. I, and Cat. Liz. iii, p. 509 (I887) ; Gïnth. Ann. and Mag. N.H. (6) i. I888, p. I68 Stejneg. Herp. Japan, p. 236, fig. (I907); Van Denb. Proc. Calif. Ac. (4) iii, I9I2, p. 247.

Body scarcely depressed. Head twice or nearly twice as long as broad, its depth equal to the distance between the centre of the eye and the tympanum, its length $3 \frac{1}{2}$ to 4 times in length to vent in males, 4 to $4 \frac{1}{4}$ times in females; snout acutely pointed, with sharp canthus and nearly vertical loreal region, a little longer than the postocular part of the head. Pileus $2 \frac{1}{5}$ to $2 \frac{1}{3}$ times as long as broad. Neck narrower than the head. Hind limb reaching the elbow or the axil in females, the axil or the shoulder in males; foot a little longer than the head. Tail $2 \frac{1}{2}$ to $3 \frac{1}{3}$ times as long as head and body.

Nostril pierced between 3 or 4 shields. Rostral sometimes entering the nostril; frontonasal as long as broad or longer than broad; præfrontals forming a usually extensive suture: frontal as long as or a little shorter than its distance from the end of the snout, $I \frac{1}{2}$ to 2 times as long as broad, narrower behind than in front; parietals $I_{3}^{1}$ to $I_{3}^{2}$ times as long as broad, often separated from the very small occipital by one 
or two small shields or by the parietals meeting in the middle. 3 or 4 supraoculars, first, if present, very small or reduced to a granule, second usually longer than the third, fourth small and sometimes broken up into granules ; f or 5 superciliaries, first and second elongate, first often in contact with the second supraocular; a complete or incomplete series of granules between the supraoculars and the superciliaries. Nasal usually forming a suture with its fellow behind the rostral" and with the anterior loreal above the postnasal, which may be very small or absent; ${ }^{3}$ anterior loreal shorter than the second; 4 , rarely $5,{ }^{*}$ upper labials anterior to the subocular, which is usually not or but little narrower beneath than above. Temporal scales very small, granular, obtusely keeled, Io to $I_{5}$ on a line between the orbit and the tympanum; an enlarged anterior upper temporal, exceptionally ${ }^{6}$ in contact with the fourth supraocular; a very narrow tympanic shield usually present.

3 pairs of chin-shields, first or first and second, exceptionally all three, ${ }^{j}$ in contact in the middle. 2 I to $3+$ gular scales in the median line, anterior granular and faintly keeled, posterior increasing in size, imbricate, keeled, and merging gradually into the plates of the very distinct collar, which are pointed, keeled, and Io to I3 in number.

Dorsal plates truncate, obtusely pointed or rounded behind, in 8 or Io, rarely 7 , longitudinal series on the body, equal or the median pair smaller and more irregular, often in ro series anteriorly and 7 posteriorly. A lateral series of large keeled scales, corresponding to tine light lateral streak, separated from the ventral plates by 2 or 3 series of smaller scales and from the dorsals by a broad granular area. Ventral plates pointed and mucronate, strongly keeled, in 6 or 8 longitudinal and 26 to .3I transverse series. 37 to 45 plates and scales round the middle of the body. Præanal plate rather large, entire and often bicarinate in males, usually longitudinally divided in females, with smaller keeled plates on the sides.

Upper surface of limbs with rhombic keeled scales. A single femorai pore on each side. Subdigital lamella mostly divided, 23 to 27 (exceptionally 3 I) under the fourth toe.

Caudal scales strongly keeled and shortly mucronate, in subequal whorls, the fourth containing If to is scales.

Bright green above; a pale yellow streak along each side, from the upper lip to the groin or to above the axil, passing below the tympanum; ' males usually with a broad grey or bronzy lateral band above the yellow streak. Lower parts greenish vellow.

Of the II type specimens before me, 5 have 4 supraoculars, 5 have 3 , and one has 4 on one side and 3 on the other In the original description I noted 4 supraoculars in Ig cases out of 26.

Van Desiburgh finds the rostral in contact with the frontonasal in about $6 \mathrm{~g}$. cent. of the specimens from Amami, in about $10 \mathrm{p}$. cent. of tlsose from Ľikaiga, and in about $5 \mathrm{p}$. cent of those fron Okinawa.

Absent in one specinen. $\quad \downarrow$ On one side only in 3 specimens

In one specimen.

6 In one specimen.-Tan Denburgh finds, 4 pairs in 12 cases, and 3 on one side and 4 on the other in 16 , out of 151 -pecinincils.

7 The specimens from Miyako examined by Van Denburgh show no trace of the light lateral streak, even on the lieac. In some of the specinens from the Northern islands there is a light lorso-lateral streak. 


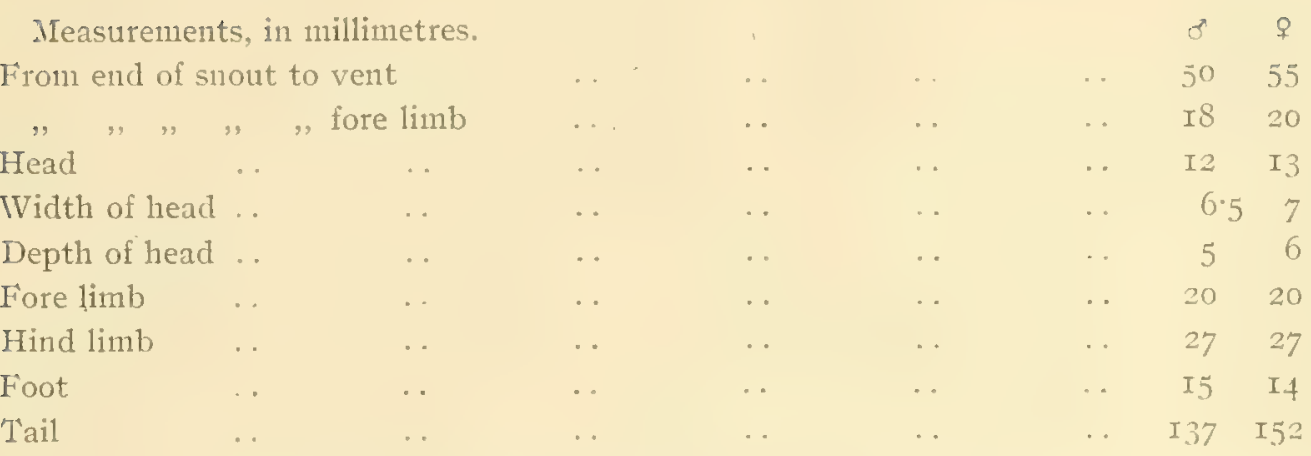

Particulars of specimens examined (the types).

\begin{tabular}{|c|c|c|c|c|c|c|c|c|c|c|c|c|}
\hline & & & & & I. & 2. & $\therefore$ & 4 & 5 & 11. & : & $\therefore$. \\
\hline$\sigma^{3}$ & .. & . & . & . & $5^{6}$ & 42 & 8 & 8 & 29 & IO & $2 \mathrm{I}$ & I \\
\hline . & & & & . & 54 & in & $\therefore$ & 1) & 211 & I ; & $\therefore 2$ & I \\
\hline , & . & . & .. & . & 49 & 37 & 8 & 6 & 32 & Io & 27 & I \\
\hline ", & . & $\ldots$ & $\ldots$ & . & 47 & 38 & 9 & 0 & 29 & II & 27 & I \\
\hline .. & 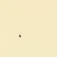 & & & & fit & in & In & $\therefore$ & 28 & 12 & $\therefore 5$ & I \\
\hline ", & . & $\ldots$ & . & . & 45 & 39 & 9 & 0 & 29 & IO & 25 & I \\
\hline q & . & $\ldots$ & & . & 55 & 40 & IO & 6 & 29 & $\mathrm{I} 2$ & 27 & I \\
\hline : & . & . & $\ldots$ & $\ldots$ & 54 & 45 & 9 & 6 & 28 & I 2 & 34 & I \\
\hline ט & . & & & & 54 & 4" & "1 & (1) & 21 & $1=$ & 20 & I \\
\hline & $\ldots$ & & $\ldots$ & $\ldots$ & 49 & 39 & 8 & 6 & 3 I & I2 & 27 & I \\
\hline & & & & & +4 & i- & & ") & $; 1$ & I : & 20 & I \\
\hline
\end{tabular}

Table as on P. 2 I2.

Habitat. Loo Choo or Riu Kiu Islands: Okinawa, Miyakoshima, Amami, Oshima, and Kikaiga.

According to Van Denburgh, the specimens from Miyakoshima have the ventrals in 8 longitudinal series and lack the light lateral streak, whilst those from the other islands have the ventrals in 6 series, rarely 8 , and the light lateral streak is present.

This is a very sharply defined species, equally remote from $T$. septentrionalis and from $T$. sexlineatus, although occupying a somewhat intermediate position between the two as regards form and lepidosis.

\section{Tachydromus sauteri, Van Denb.}

Takydromus santeri, Van Denb. Proc. Calif. Ac. (4) iii. Igog, p. 50, and t.c. I9I2, p. 25 I.

Body scarcely depressed. Head twice or nearly twice as long as broad, its depth equal to the distance between the centre of the eye and the tympanum, its length 4 times in length to vent in males, $4 \frac{1}{4}$ times in females; snout acutely pointed, with sharp canthus and nearly vertical loreal region, a little longer than the postocular part of the head. Pileus $2 \frac{1}{4}$ to $2 \frac{1}{3}$ times as long as broad. Neck narrower than the head. Hind limb reaching the elbow in females, the axil in males; foot a little longer than the head. Tail $3 \frac{1}{2}$ to 4 times as long as head and body.

Nostril pierced between 4 or 5 shields. Rostral entering the nostril ; frontonasal 
longer than broad; profrontals forming an extensive suture; frontal a little shorter than its distance from the end of the snout, $I_{3}^{2}$ times as long as broad, narrower behind than in front; parietals $I_{3}^{2}$ times as long as broad; interparietal $I \frac{1}{2}$ to $I \frac{2}{3}$ times as long as broad, separated from the very small occipital by the parietals meeting in the iniddle. + supraoculars, first very small, second longer than the third, fourth small but larger than the first; 3 superciliaries, first and second elongate; a complete series of granules between the supraoculars and the superciliaries. Nasal usually forming a suture with its fellow behind the rostral ${ }^{1}$ and in contact with the anterior loreal above the postnasal, unless its posterior portion be detached to form a second postnasal; ${ }^{2}$ anterior loreal as long as or shorter than the second; 4 upper labials anterior to the subocular, which is not or but little narrower beneath than above. Temporal scales very small, granular, obtusely keeled, I2 on a line between the orbit and the tympanum; a feebly enlarged anterior upper temporal; a very narrow tympanic shield.

4 pairs of chin-shields, "the 3 anterior in contact in the middle. 22 to 24 gular scales in the median line, anterior granular and faintly keeled, posterior increasing in size, imbricate, keeled, and merging gradually into the plates of the very distinct collar, which are pointed, keeled, and Io to 12 in number.

Dorsal plates obtusely pointed or rounded behind, in 7 or 8 longitudinal series on the body, the median smaller. Ventral plates obtusely pointed and mucronate, very strongly keeled, in 6 longitudinal and 27 or 28 transverse series. 2 or 3 series of keeled scales on the side above the ventral plates, separated from the dorsals by a broad granular area. 28 to 32 plates and scales round the middle of the body. Præanal plate rather larger, ${ }^{6}$ bicarinate, with one or two smaller keeled plates on each side.

Upper surface of limbs with rhombic keeled scales. A single femoral pore on each side. Subdigital lamellæ single, or partly single and partly paired, 24 under the fourth toe.

Caudal scales strongly keeled and shortly mucronate, in subequal whorls, the fourtl containing I2 or It scales.

Bright green above; a white streak along each side, from the upper lip to the groin, passing beiow the tympanum and along the upper half of the outer row of ventral plates, continued on the base of the tail. I,imbs and tail often reddish. One of the specimens described by Van Denburgh has a dark red-brown band along the side, from the eye, just above the white streak, to the tail, where it spreads over the upper surface. Lower parts white.

Rostral in contact with the frontonasal in 2 specimens out of 5 I examined by Van Denburgli.

As in one of the two speciumens here described.

5 in the type specimen deseribed by Van Denburgh.

+ 5 in one specimen, 3 - + in another, according to Van Deuburgh.

According to Van I enburgh, there are usually two median series of small plates anteriorly and oue posterioriy, or ;-2-1, 2-I-O, ] througlout, or I-O. Onc specinen has only i row of large plates on eacli side of the back, separated by about 7 rows of swaller, irregular plates

lixceptionally divided, according to lian I)enburgh 
Measurements, in millimetres.

From end of snout to vent ..

Head.

. . .

IVidth of head

Depth of head

Fore limb

Hind limb

Foot .

Tail

\begin{tabular}{|c|c|c|c|c|c|}
\hline & & . & & $\sigma^{\pi}$ & q \\
\hline$\cdots$ & . & . & . & 52 & 55 \\
\hline . & $\cdots$ & . & . & I9 & I9 \\
\hline . & $\cdots$ & . & $\cdots$ & I3 & $I_{3}$ \\
\hline . & $\cdots$ & . & $\ldots$ & 7 & 6.5 \\
\hline . & $\cdots$ & $\ldots$ & . & 6 & 5.5 \\
\hline$\cdots$ & $\cdots$ & $\ldots$ & $\ldots$ & 22 & 20 \\
\hline$\cdots$ & . & $\cdots$ & . & 26 & 26 \\
\hline$\cdots$ & $\cdots$ & $\cdots$ & $\ldots$ & I5 & I4 \\
\hline$\ldots$ & . & $\ldots$ & . & $20(x)$ & I 115 \\
\hline
\end{tabular}

\section{Particulars of specimens examined.}

$$
\text { o, Cochun }
$$$$
\text { q }
$$

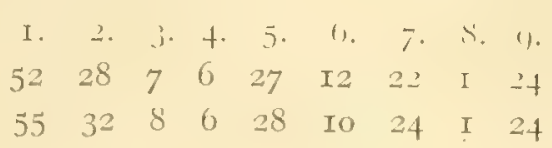

Table as on p. 2 I2.

Habitat. Formosa.

Closely allied to $T$. smaragdinus, but readily distinguished by the number of chin-shields, the lower number of plates and scales round the middle of the body, the longer tail, and the position of the light lateral streak.

\section{Tachydromus sexlineatus, Daud.}

Takydromus sexlineatus, Daud. Hist. Rept. iii, p. 256, pl. xxxix (I802); Brongn. Mém. Sav. Etr. Ac. Paris, i. I806, p. 627, pl. ii, fig. 8; Dum. et Bibr. Erp. Gén. r, p. I58 (r839); Gray, Cat. Liz., p. 52 (I845); Günth. Rept. Brit. Ind., p. 69, pl. viii, fig. C. (I864); Stoliczka, Journ. As. Soc. Beng. xii, 1872, p. 87; Günth. Nov. Zool. ii. I895, p. 499 ; Iaidlaw, Proc. Zool. Soc. Igor, p. 310 ; Annandale, Journ. As. Soc. Beng. (2) i. I905, p. I40 ; Bouleng. Vert. Faun. MIal. Pen., Rept., p. 79 (IgI2); De Rooij, Rept. Ind.-Mal. Arch. i, p. I54, fig. (Igr5).

Takydromus quadrilineatus, Daud. t. c., p. 252.

Tachydromus ocellatus (Cuv.), Guér. Icon. R. An., Rept.pl.vi, fig. 3 (I829); Duvern. R. An., Rept. pl. xi (I836).

Tachydromus typus, Gray, Ant1. N.H. i. 1838 , p. 389.

Tachydromus sexlineatus, var. eneofuscus, Peters. Mon. Ber1. Ac. I863, p. 405.

Tachydromus meridionalis, Günth. Rept. Brit. Ind. p. 70, pl. viii, fig. D, and Ann. and Mag. N.H. (6) i. 1888 , p. 167 .

Tachydroms sexlineatus, part., Bouleng. Cat. Liz. iii, p. 4 (I887), and Faun. Ind., Rept. p. I69) (I89o); Günth. Anu. and Mag. N.H. (6) i. I888, p. 167.

Tachydromus sikkimensis, Günth 1.c.

Body not depressed. Head about twice as long as broad, its depth equal to the distance between the centre of the eye and the tympanum, its length $3 \frac{2}{3}$ to $4 \frac{1}{6}$ times in length to vent in males, 4 to $4 \frac{1}{3}$ times in females; snout acutely pointed, with sharp canthus and nearly vertical loreal region, as long as the postocular part of the head. Pileus $2 \frac{1}{5}$ to $2 \frac{1}{3}$ times as long as broad. Neck narrower than the head. Hind limb reaching the elbow or the axil; foot as long as or a little longer than the head Tail 3 to 5 times as long as head and body.

Nostril pierced between 3 or 4 shields. Rostral sometimes entering the nostril; upper head-shields smooth or feebly rugose; frontonasal as long as broad or longer 
than broad; prefrontals forming a median suture; frontal as long as or shorter than its distance from the end of the snout, $I \frac{1}{2}$ to 2 times as long as broad, narrower behind than in front; parietals $I_{3}^{2}$ to 2 times as long as broad; interparietal $I_{2} \frac{1}{2}$ to 2 times as long as broad; occipital usually shorter than the interparietal, sometimes nearly as long and a little broader, sometimes separated from it by one ${ }^{2}$ or two ${ }^{3}$ small shields, or by the parietals meeting in the middle. 3 supraoculars, first longer than the second and in contact with the second loreal, third small and rarely ${ }^{6}$ in contact with the frontoparietal; 3, very rarely 4, superciliaries, second longest; granules between the supraoculars and the superciliaries absent or reduced to one or two. Nasal usually forming a very short suture with its fellow behind the rostral ${ }^{6}$ and with the anterior loreal above the postnasal $;^{7}$ anterior loreal shorter than the second; 4 upper labials, rarely $3^{3}$ or 5, anterior to the subocular, which is narrower beneath than above. Temporal scales moderately large, rhombic or hexagonal, strongly keeled; one, two, or three large, keeled upper temporals, first very rarely ${ }^{10}$ in contact with the fourth supraocular; a long and narrow tympanic shield.

3 pairs of chin-shields, ${ }^{11}$ first or first and second in contact in the middle; 5 to 24 gular scales on the median line, anterior narrow, juxtaposed, feebly keeled, then increasing in size, imbricate, pointed, keeled, and merging gradually into the rather indistinct collar, which is composed of 8 to 12 plates.

Dorsal plates truncate and shortly mucronate behind, in 6 or 8 longitudinal series on the neck, + or 6 on the anterior part of the body; 4 , very rarely 6 , in the middle of the body, $f$ on the lumbar region. ${ }^{12}$ Ventral plates obtusely pointed and shortly mucronate, strongly keeled, in I o or 12 longitudinal and 2 I to 28 transverse series. A rather irregular series of large keeled scales borders the ventral plates and is separated from the dorsals by a granular area. 28 to 38 plates and scales round the mildle of the body. Præanal plate rather large, more or less distinctly bicarinate, with smaller keeled plates on the sides.

Upper surface of limbs with rhombic keeled scales. I or 2 , very rarely 3 , femoral pores on each side. ${ }^{13}$ Subdigital lamellæ single or partly divided, I8 to 26 under the fourth toe, usually 2 I to 26.

In one specimen from Bormeo.

In one specimen from Saigon.

t Single specimens from S. China, Saigon, Rangoon and Java,

b One specimen from S. China, one from Saigon, and two from Great Natuna.

In single specimens from Ma Son MIts, Great Natuma, and lorneo, the rostral is narrowly in contact with the trontonasai.

7 In one specinen from Saigon the posterior portion of the masal is detached to form a second postnasal; the postnasal is absent on one side in a specimen from Matang.

Y On both side in one specinen from Great Natuna and in one from Java; on one side in one from Matang and in one from Java.

4 ()n one side in two specimens from Saigon and in one from Great Natuna. 10 In one specimen from Matang.

1 There are exceptions. Out of 25 specimens from Sikkim Stoliczka found + with 4 pairs and one with 3 shields on one side and 4 on the other. Annandale fonnd 2 with 4 pairs ont of 27 from the I astern Himalayas, Assam and Burma. 'liere is sometimes irregularity on the two sides of the same specimen; thus in a fenale from Siam there are plates on one side and 3 on the other in the two transverse series of dorsal plates just before the middle of the body.

Stoliczka's statement that they vary from 3 to 6 in sikkin specimens recuires confination. The specimens on which his description is based are not in the Calcutta Inseun, I)r. Annandale informs me. 
Caudal scales strongly keeled and mucronate, the keels forming 4 very strong ridges on the upper surface of the basal part of the tail, the whorls nearly equal in length, the fourth or fifth containing I 2 to I 8 scales.

Greenish olive, bronze brown, or reddish above, with metallic gloss; usually a white or whitish dorso-lateral streak, 'often edged with a black line or a broad black band, originating on the superciliary edge or just behind the parietal shield; the black band bordering the white streak produced on the side of the head; a white, sometimes black-edged streak from the loreal region to the shoulder, passing through the middle of the tympanum, sometimes continued on the side of the body; males often with a series of small white, black-edged ocelli above the lower lateral streak; hinder side of thigh often with a black streak; limbs and tail often reddish. Lower parts yellowish or greenish white.

Measurements, in millimetres.

From end of snout to vent

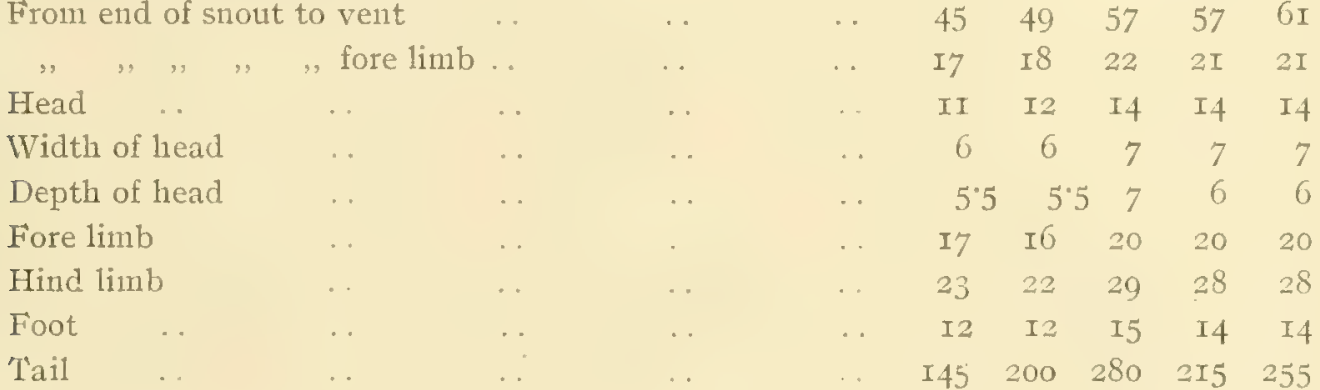

I. $\sigma^{\pi}$, S. China, type of $T$. mcridionalis. 2. $q$, ditto. 3. $0^{\pi}$, Great Natuna. 4. $0^{\pi}$, Java. 5. Q, Matang.

\section{Particulars of specimens examined.}

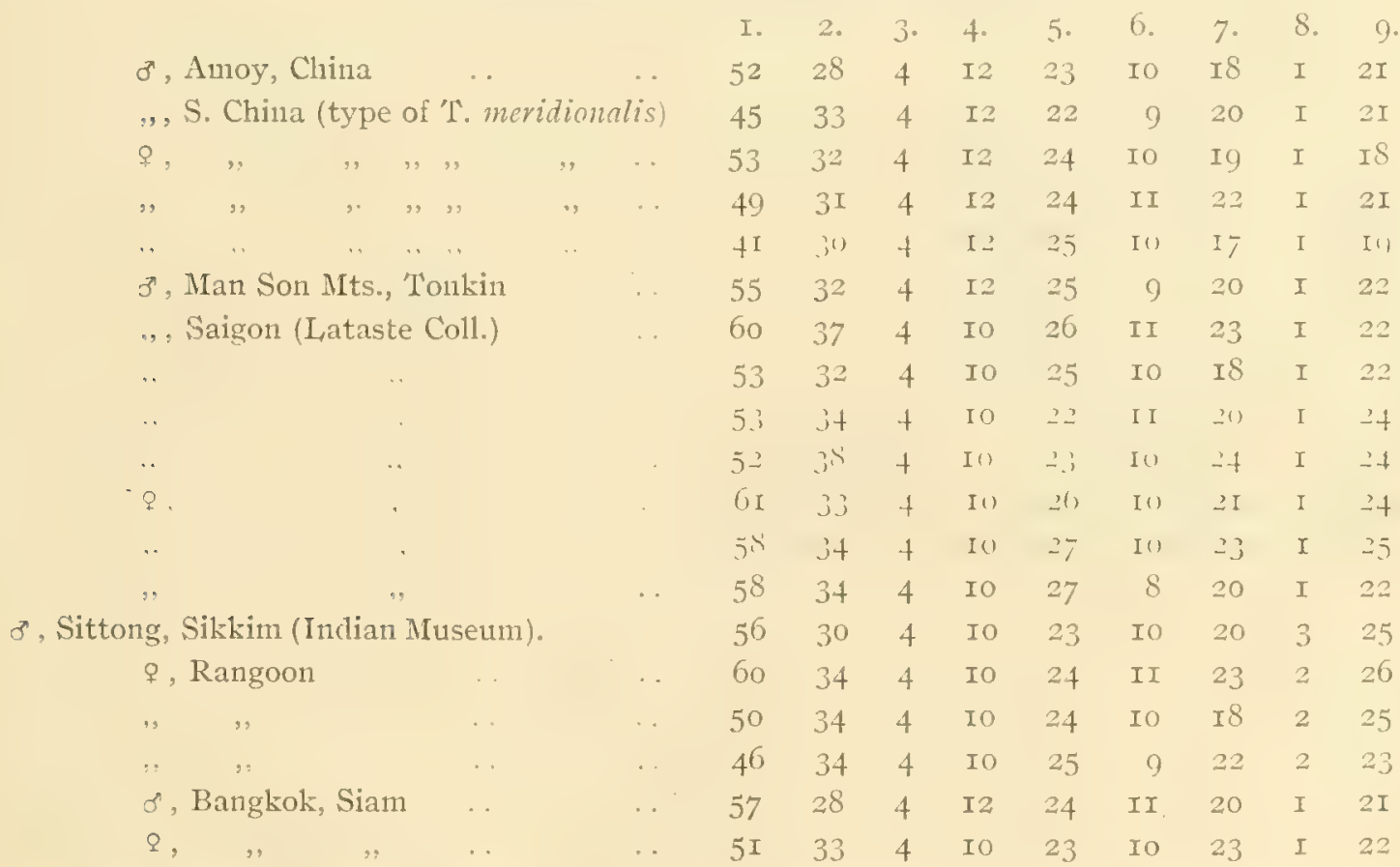




$$
\begin{aligned}
& \text { ?, Maprit, Siann } \\
& \text { Jalor } \\
& \text { ร, Crreat Natuna Id. }
\end{aligned}
$$

6, Matang, Bormeo

q

d, Borneo ..

3

o, Java

?

Table as on p. 212.

Habitat. From Southern China and the Eastern Himalayas through Indo-China, Assam, Burma, Siam, and the Malay Peninsula to the Malay Archipelago (Natuna Islands, Sumatra, Banka, Borneo, Java). Reaches an altitude of I,200 m. in Java.

\section{I0. Tachydromus haughtonianus, Jerd.}

Tachydromus hanghtonianus, Jerdon, Proc. As. Soc. Beng. I870, p. 72 ; Anders. Proc. Zool. Soc. I87 I, p. I56: Stoliczka, Journ. As. Soc. Beng. xli, I872, p. 88; Günth. Ann. and Mag. N.H. (6) i, I888, p. I69.

Tachydromus scptcurionalis, (non Günth.), Annandale, Proc. As. Soc. Beng. (2) i, I005, p. I39.

Body not depressed. Head $2 \frac{1}{3}$ times as long as broad, its depth equal to the distance between the centre of the eye and the tympanum, its length $4 \frac{1}{4}$ times in length to vent; snout acutely pointed, with sharp canthus and nearly vertical loreal region, as long as the postocular part of the head. Pileus $2 \frac{1}{2}$ times as long as broad. Neck a little narrower than the head. Hind limb reaching the axil; foot as long as the head. 'Tail $2 \frac{2}{5}$ times as long as head and body.

Nostril pierced between + shields. Rostral entering the nostril; upper headshields smooth; frontonasal longer than broad; profrontals forming a median suture ; frontal shorter than its distance from the end of the snout, I $\frac{2}{3}$ times as long as broad, narrower behind than in front; parietals nearly twice as long as broad; interparietal $I_{2}^{1}$ times as long as broad; occipital as broad as and shorter than the interparietal. 3 supraoculars, first longer than the second and in contact with the second loreal, third very small and narrowly separated from the frontoparietal; 5 superciliaries, second longest, all in contact with the supraoculars. Nasal forming a very short suture with its fellow behind the rostral and with the anterior loreal above the postnasal; anterior loreal shorter than the second; 4 or 5 upper labials anterior to the 
subocular, which is as broad beneath as above. Temporal scales very small, hexagonal, keeled; two large upper temporals, keeled above, first not in contact with the fourth supraocular; a long and narrow tympanic shield.

4 pairs of chin-shields, the 3 anterior in contact in the middle; 26 gular scales in the median line, anterior narrow, juxtaposed, smooth, posterior increasing in size, imbricate, pointed, strongly keeled, and passing gradually into the ventral plates, there being no trace of a collar.

Dorsal plates truncate and shortly mucronate behind, in 6 longitudinal series on the neck and body. Ventral plates truncate and shortly mucronate, strongly keeled, in Io longitudinal and 30 transverse series; no large scales bordering the ventral plates. 32 plates and scales round the middle of the body. Praeanal plate large, bicarinate, with smaller keeled plates on the sides.

Upper surface of limbs with rhombic keeled scales. A single femoral pore on each side.' Subdigital lamellæ single, 22 under the fourth toe.

Caudal scales strongly keeled and shortly mucronate, the keels forming 6 ridges on the upper surface of the basal part of the tail ; the whorls nearly equal in length. the fourth containing I 8 scales.

Reddish brown above, with a broad whitish streak on each side, proceeding from the superciliary edge; below this a dark brown lateral streak, proceeding from the nostril and passing through the eye and the tympanum; limbs reddish. Lower parts yellowish white.

Measurements, in millimetres.

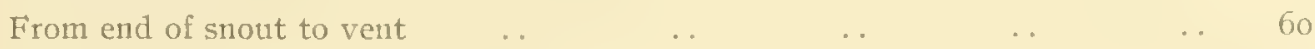

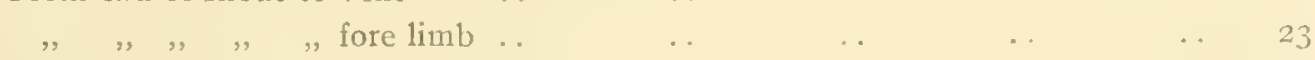

\begin{tabular}{llllllllll} 
Head & $\ldots$ & & $\ldots$ & $\ldots$ & $\ldots$ & $\ldots$ & $\ldots$ & & \\
\hline
\end{tabular}

$\begin{array}{lllllllll}\text { IVdith } \text { of head } & \ldots & \ldots & \ldots & \ldots & \ldots & \ldots\end{array}$

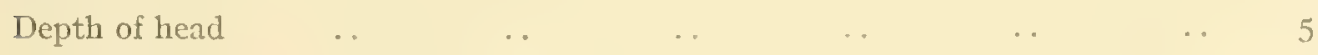

$\begin{array}{llllllllll}\text { Fore limb } & \ldots & \ldots & \ldots & \ldots & \ldots & \ldots & \ldots & \end{array}$

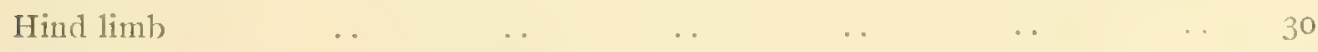

$\begin{array}{lllllllll}\text { Foot } & \ldots & \ldots & \ldots & \ldots & \ldots & \ldots & \ldots & \end{array}$

$\begin{array}{llllllllll}\text { Tail } & \ldots & \ldots & \ldots & \ldots & \ldots & \ldots & \ldots & \\ \end{array}$

This species is known from a single male specimen, from Goalpara in Assam, preserved in the Indian Museum, Calcutta, which has been kindly entrusted to me for description by Dr. Annandale.

It is closely allied to $T$. sexlineatus, but differs in the still narrower head, the shorter tail, the number of series of dorsal plates, the smaller temporal scales, and the total absence of a collar.

\section{Platyplacopus, g. n.}

Head-shields normal. Nostril pierced between the nasal, one or two postnasals, and the first upper labial. Lower eyelid scaly. Collar distinct: Back with large, plate-like, imbricate scales with strong keels forming continuous lines; sides with

1 Günther's statement that there are 2 pores is due to a misunderstanding of Anderson's description, which mentions "one pair of femoral pores." 
granular scales; ventral plates obtusely pointed, imbricate, smooth or feebly keeled. Digits slightly depressed, with large transversely elliptic smooth lamellæe inferiorly, the distal joint compressed, bent at an angle and covered with narrow lamellæ inferiorly. Femoral pores reduced to 3 to 5 on each side. Tail very long, cylindrical.

Southern China and Formosa.

Distinguished from Tachydromus by the structure of the digits, which reproduces the condition known in the Geckonid genus Gymmodactylus. In this respect it is more specialized than Tachydromus, whist nearer to Lacerta in having occasionally as many as 5 femoral pores.

\section{Platyplacopus kuehnei, Van Denb.}

Tachydromus kuchnei, Van Denb. Proc. Calif. Ac. (4) iii, rnoo, p. 50 , ancl t. c. I9I2, p. 252; '1. Vogt. Sitzb. Ges. Nat. Fr. Berl., I9I4, p. 99.

Body feebly depressed. Head flat above, nearly twice as long as broad, its depth equal to the distance between the centre of the eye and the tympanum, its length $3 \frac{1}{2}$ times (male) in length to vent; snout acutely pointed, as long as the postocular part of the head, with sharp canthus and vertical loreal region. Pileus slightly more than twice as long as broad. Neck narrower than the head. Hind limb reaching the axil (male); foot as long as the head. Tail more than twice as long as head and body.

Nostril pierced between 3 or 4 shields. Rostral not touching the nostril, rarely in contact with the frontonasal; upper head-shields rather rough with faint strix and pits; frontonasal a little longer than broad; præfrontals forming an extensive median suture; frontal with a median keel, a little shorter than its distance from the end of the snout, as long as the frontoparietals, $\mathrm{I}_{3}$ times as long as broad, a little narrower behind than in front; parietals $I_{3}^{2}$ times as long as broad; interparietal $I_{2}^{1}$ times as long as broad, separated from the smaller occipital by a short suture formed by the parietals. 4 supraoculars, first very small, second and third equal, fourth small; 4 superciliaries, first and second elongate, first in contact with the second supraocular and followed by a series of granules. ${ }^{2}$ Two superposed postnasals ${ }^{3}$; anterior loreal much shorter than the second; 4 upper labials anterior to the subocular, which is a little narrower beneath than above. Temporal scales very small, granular, keeled; an enlarged anterior upper temporal, not in contact with the fourth supraocular; a very narrow tympanic shield.

4 pairs of chin-shields, the 3 anterior in contact in the middle; 28 gular scales on the median line, anterior granular, posterior increasing in size, imbricate, feebly keeled, and merging gradually into the plates of the collar, which are pointed, feebly keeled, and I in number.

Dorsal plates truncate behind, in $6^{*}$ regular longitudinal series, with a vertebral

According to Vogt. $\quad 2$ The series sometimes complete, according to Van Denburgh.

This is probably an indiridual abnormality in the specinen examined by me, as 110 mention is made by Van Deniburgh of two postnasals.

+4 serics in one specinen ont of 1,3 , according to Van I) enlurgh 
series of small scales anteriorly. Ventral plates in 6 longitudinal series, only the outer keeled; 28 transverse series. Sides minutely granular. 42 plates and granules round the middle of the body. Præanal plate rather small, bordered by one semicircle of small smooth plates.

Upper surface of limbs with rhombic keeled scales. 4 femoral pores on each side. 23 lamellar scales under the fourth toe.

Caudal scales strongly keeled and shortly mucronate, the whorls alternately a little longer and shorter, the fourth containing 18 scales.

Olive-brown above, the dorso-lateral area (two rows of plates) lighter; two biackish streaks, formed of spots close together, along the middle of the back; a blackish lateral band, from the nostril, through the eye and involving the upper half of the ear-opening, to the base of the tail, dotted with whitish on the body; reproduced tail reddish. Lower parts white.

The specimen selected as the type is thus described by Van Denburgh :-

"The colour above is greenish olive, becoming lighter yellowish olive on the limbs and tail. The sides are dark olive brown. A light line, edged above with dark brown, starts at the nostril, crosses the lower eyelid, the lower part of the earopening, and fades away above the axilla. 'The upper labials, dorsals, limbs and tail are dotted or spotted with dark brown. The lower surfaces are greenish white, tinged with orange on the tail."

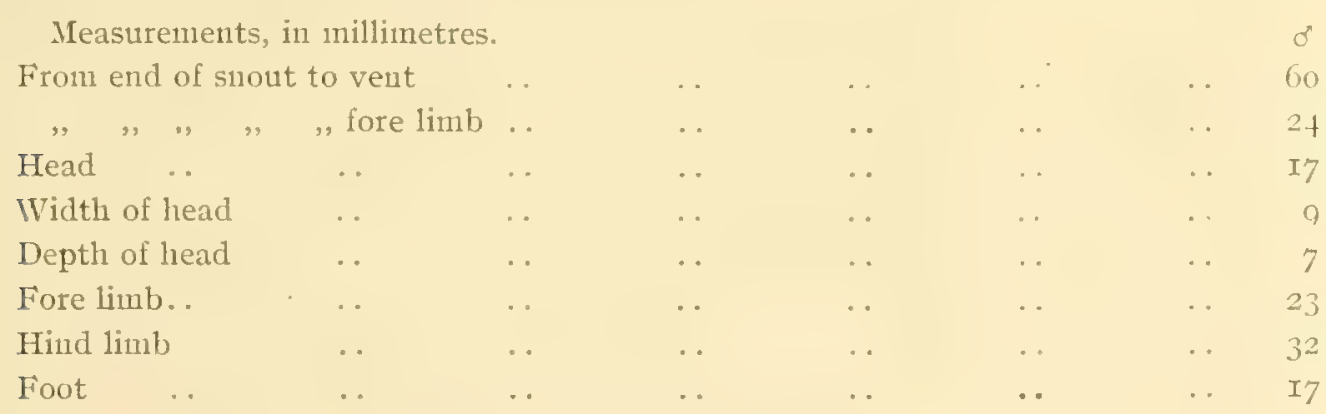

Habitat. This remarkable species was described from I3 specimens from Kallshirei and Taipeh, Formosa; one of these is now preserved in the British Museum. It has since been reported from Southern China, near Canton, by T. Vogt.

Tachydromus chinensis, T. Vogt, Sitzb. Ges. Nat. Fr. Berl. I9I4, p. 98, is said to be similar to $P$. kuchnei, but there are only 3 pairs of chin-shields and the ventral plates are obtusely keeled. 3 femoral pores on each side.-Northern parts of the Province Kuangtung, Southern China.

\section{Apeltonotus, g. n.}

Head-shields normal. Nostril pierced between the nasal, a postnasal, and the first upper labial. Lower eyelid scaly. Collar distinct. Dorsal scales small, hexago11al, subimbricate, keeled; ventral plates obtusely pointed, imbricate, of median rows smooth or faintly keeled, of outer row strongly keeled. Digits compressed, with

1 Of the I 3 types and co-types, 8 have 4 pores, 4 have 5, and I has $4-5 .-3$ or 4 pores in specimens from Canton according to Vogt. 
smooth scales inferiorly. Femoral pores reduced to 2 or 3 on each side. Tail very long, cylindrical.

Loo Choo Islands.

This genus is very closely allied to Tachydromus, to which it stands in the same relation as Bedriagaia to Poromora among African genera. Could we find a lizard combining the dorsal scales of Apeltonotus with the other characters of Tachydromus ammensis, we would have the connecting link between the latter and Lacerta viviberu.

\section{Apeltonotus dorsalis, Stejneg.}

Takydromus dorsulis, Stejneg. Smithson. Quart. Misc. Coll. xlvii, 1905, p. 294, and Herp. Japan, 1). 229, fig. (Ig07); Van Denb. Proc. Calif. Ac. (4) iii, I9I2, p. 242 ,

Body slender, feebly depressed. Head $I_{4}^{3}$ times as long as broad, its depth equal to the distance between the centre of the eye and the tympanum, its length about 4 times in length to vent; snout acutely pointed, a little longer thin the postocular part of the head, with sharp canthus and vertical, concave loreal region. Pileus $2 \frac{1}{4}$ times as long as broad. Neck a little narrower than the head. Limbs slender, with very long digits; the hind limb reaches the shoulder in males, not beyond the axil in females; foot a little longer than the head. Tail 3 to $3 \frac{1}{2}$ times as long as head and body.

Nostril between 3 shields; nasals forming a very short suture behind the rostral ; frontonasal much longer than broad; præfrontals forming an extensive suture; frontal as long as its distance from the end of the snout, about $\mathrm{I}_{\frac{2}{3}}$ times as long as broad, narrower behind than in front; parietals about $I \frac{1}{2}$ times as long as broad, outer border convex; interparietal small, narrow, a little longer than the occipital ; 3 or $f$ supraoculars, if $t$, first small and granular, followed by a series of granules separating the supraoculars from the superciliaries, which are 5 in number. Rostral barely entering the nostril; a single postnasal; anterior loreal much smaller than the second; 4 upper labials, rarely 5 or 3 , anterior to the subocular. Temporal scales small, strongly keeled; an enlarged, keeled anterior upper temporal shield; a short and very narrow tympanic slield.

+ pairs of chin-shields," the 3 anterior in contact in the middle; gular scales granular anteriorly, gradually enlarged, imbricate, and keeled towards the collar, 26 in a straight median line; collar-plates large, pointed, keeled.

Scales strongly keeled, those on the back larger, about 5 corresponding to 3 ventral plates; 28 to 30 scales across the middle of the body. Ventral plates in 6 longitudinal series, the outer strongly keeled, the others smooth or feebly keeled; 24 transverse series. Preanal plate large, smooth, bordered by a semicircle of small plates, or with two small plates on each side.

Scales on upper surface of limbs large, keeled, larger than the dorsals, on forearm smooth and forming transverse plates. Usually 2, rarely 3, femoral pores on each side. 20 lamellar scales under the fourth toe.

I Rustral in contact with the frontonasal in nue specimen examined by Vau Denburgl.

2 Van I) 
Caudal scales strongly keeled, twice as large as largest dorsals, I6 in the fourth whorl.

Bluish slate above, probably greenish in life; a black line from the nostril through the eye to the centre of the ear-opening; a pale, probably yellowish, streak below this from the nostril through the lower eyelid to the lower border of the earopening; lower parts greenish or yellowish white.

Measurements, in millinetres.

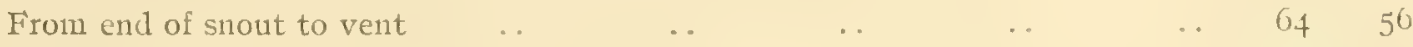

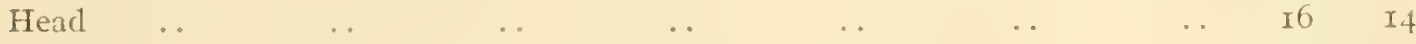

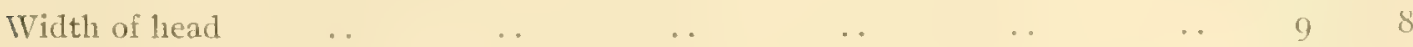

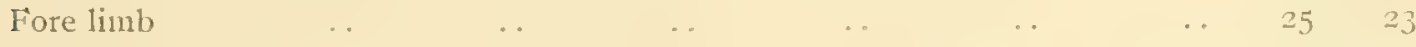

$\begin{array}{llllllllll}\text { Hind } \operatorname{limb} & \ldots & \ldots & \ldots & \ldots & \ldots & \ldots & \ldots & \ldots & \end{array}$

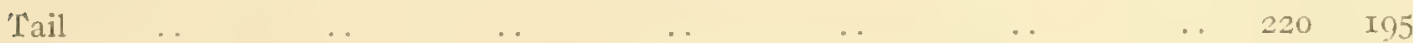

The above description is compiled from those of Stejneger and of Van Denburgh and from one of the co-types received from the U.S. National Museum.

Habitat. Ishigaki Island, in the Southern Group of the Loo Choo or Riu Kiu Archipelago. The type is preserved in the U.S. National Museum. 



\section{EXPI,ANATION OF PIATE XI,VI.}

FiG. I. - Tachydromus ammensis. \&, Chabarovka.

., 2.-Laccrta vivipara. \&. Scotland.

$\therefore$ 3.-Tachydromms wolleri. of Seoul.

.. t.Tachydromus formosames. 's'aipeh.

a. Side view of head. b. Upper view of head. c. I, ower view of head. d. I,ower view of posterior part of body and hind limb.

Whole lizards natural size, details magnified 2 diameters. 


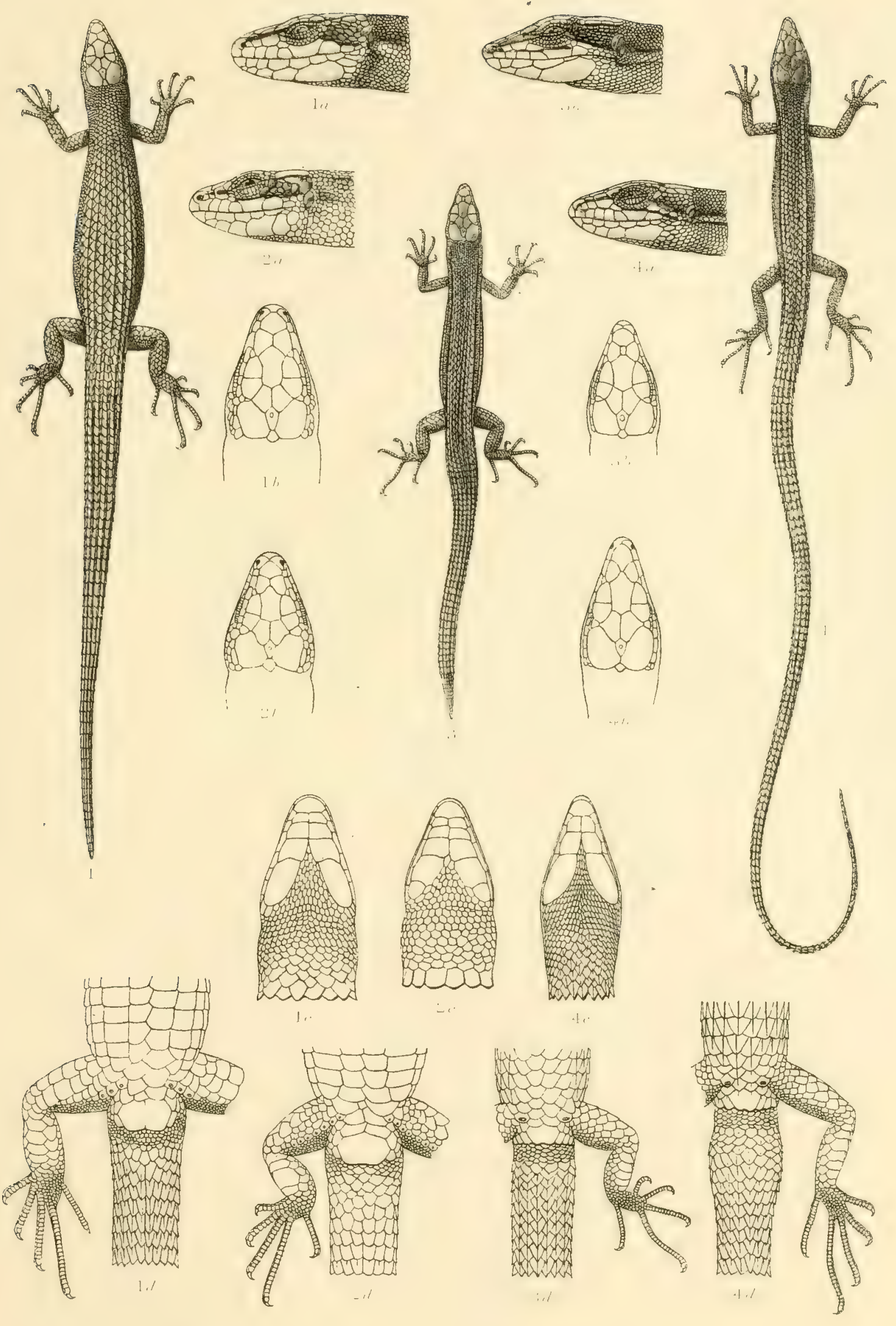




EXPLANATION OF PLATE XI,VII.

FIG. I.-Tachydromus khasiensis. \&, Khasi Hills.

," 2.--Tachydromus sauteri. 8, Coshun.

, 3.-Platyplacopus kuehnei. c", Kanshirei.

a. Side view of head. b. Upper view of head. c. Lower view of head. $d$. Lower view of posterior part of body and hind limb. e. Lower surface of foot.

Whole lizards natural size, details magnified 2 diameters. 

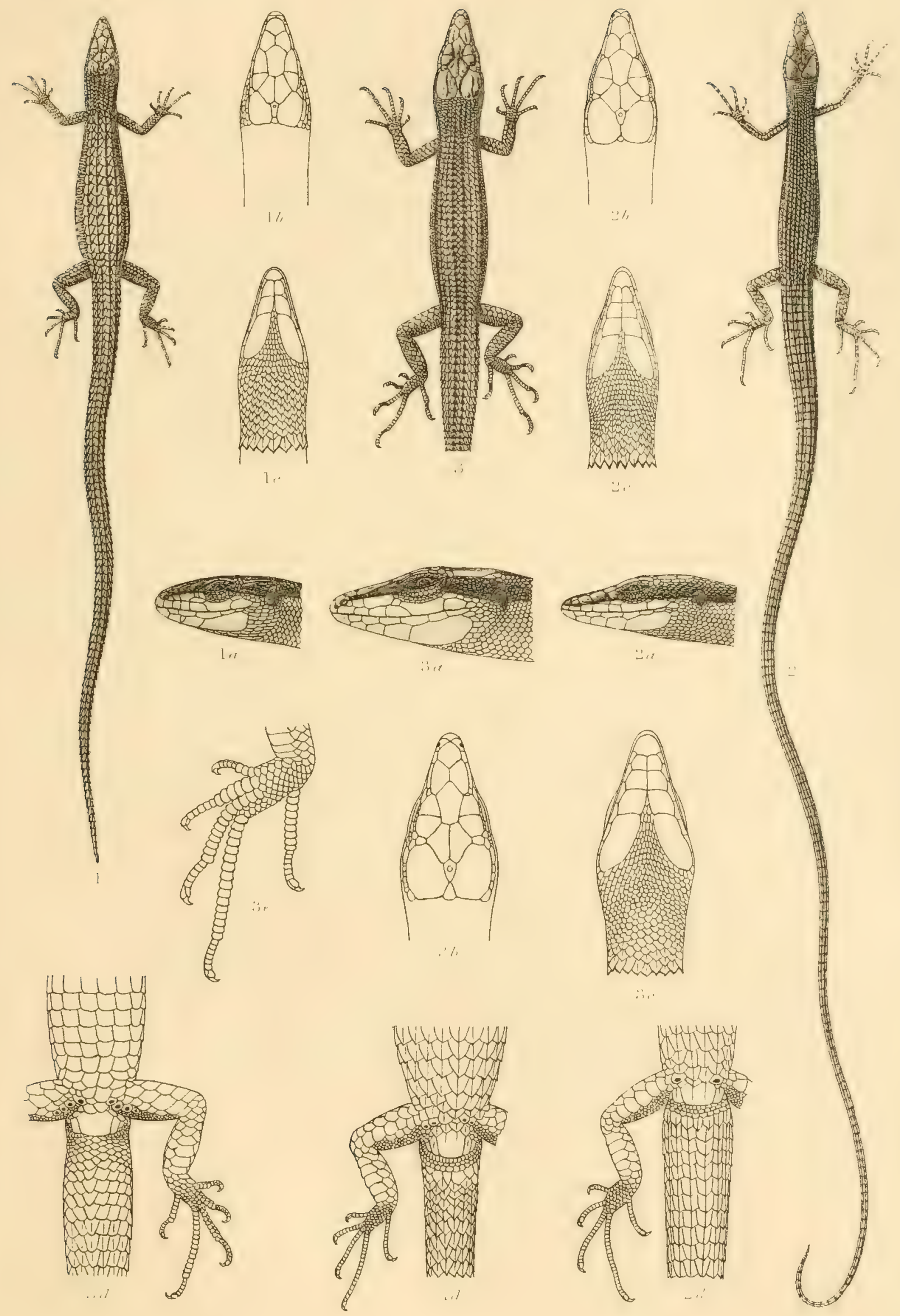


.




\section{Memoirs of the Asiatic Society of Bengal.}

Vol. 1.

1. On certain Tibetan Scrolls and Inages lately brought from Gyantse.-By Prof. Satis Chandra Vidfabioșana, M.A., M.R.A.S. (Price Re. I-8; or $2 s .3 d$.)

II. Sizl-Ammoniac: a Study in Primitive Chemistry.-By H. E. Srapleton, B.A., B.Sc. (Price Re. I ; or Is. 6d.)

A. H. FRANCKe. (Price Rs. 2 ; or 2s. rod.)

III. The Similarity of the Tibetan to the Kashgar-Brahmi Alphabet.-By The REv.

IV. Alchemical Equipment in the Eleventh Century, A.D.-By H. E. Stapleton and

R. F. Azo. (Price Re. 1-8; or 2s. 3a.)

V. Malay'sian Barnacles in the Indian Mnuseum, with a list of the Indian Pedunculata.By N. Annandale, B.A., D.Sc. (Price Re. I-8; or 2s. 3 d.)

VI. Ashrafpur Copper-plate Grants of Devakhadga.-By Ganga Mohan Laskar, M.A. (Price Annas 8 ; or Iod.)

VII. Festivals and Folklore of Gilgit.-By Ghulam Munammad. (Price Rs. 2 ; or 2s. rod.)

VIII. Notes on the Bhotias of Almora and British Garhwal.-By C. A. Sherring, M.A.

F.R.G.S., I.C.S. (Price Re. I-5; or 2s.) [R.s. 2 ; or $2 s .10 d$.)

IX. Religion and Customs of the Uraons.-By the late REV. FAther Denon, S.J. (Price

X. Notes on the Fauna of a Desert Tract in Southern India. (Herpetology and

Entomology).-By N. Anvandale, D.Sc., C.M.Z.S., with a list of Mammals

by R. C. Wroughton, F.E.S. (Price Rs. 2 ; or $2 s$. iod.)

XI. Amulets as Agents in the Prevention of Disease in Bengal.-Compiled in the Office of the Superintendent of Ethnography, Bengal. (Price Annas 12 ; or Is. $2 d$.)

XII. Earth-Eating and the Earth-Eating Habit in India.-By D. Hooper and H. H. Mann. (Price Re. I ; or Is. 6d.)

XIII. On a Cup-Malk Inscription in the Chumbi Valley-By E. H. C. WALSH, I.C.S.

XIV. A Descriptive List of the Sea-Snakes (Hydrophiidx) in the Indian Museum, Calcutta.

- By Captain F. Wall, I.M.S., C.M.Z.S. (Price Re. I; or $1 s .6 d_{0}$.)

XV. Common Saws and Proverbs collected, chicfly from Dervishes, in Southern Persia.-By Lievt.-Col. D. C. Philloti:. (Price Re. I ; or is. 6d.)

XVI. The Common Hydra of Bengal: its Systematic Position and Life History.-By N. Annandale, B.A., D.Sc., C.M.Z.S. (Price Re. I ; or Is. 6d.)

XVII. Animals in the Inscriptions of Piyadasi.-By Monmohan Chakravarti, M.A. (Price Annas I 2 ; or Is. 2d.)

XVIII. Some current Persian Tales told by Professional Story-Tellers.-By Lieut.-Col.

D. C. Phillott. (Price Re. I ; or Is. 6d.)

XIX. The Dards at Khalatse in Western Tibet.-By REv. A. H. FRANcke. (Price Supplement, Miscellanea Ethnographica. Part I. I. The Blow-Gun in Southern India 2. Miscellaneous objects from the Rámanád subdivision of the Madura district 3. Indian Weighing-beams.-By N. Annandale, D.Sc. (Price Re. I.)

Supplement, Miscellanea Ethnographica. Part II. 1. Some Malayan Weapons-By N. Annandale. 2. Plan of a Persian Gentleman's House.-By Lieut.-Col. D. C. Phillotr. (Price Annas 8 ; or Iod.)

Vol. II.

1. Cirrhipèdes operculés de l'Indian Museum de Calcutta.-Par M. A. GRuver. (Price Rs. 2 ; or 2 s. 10 .)

II. The Coinage of Tibet.-By E..H. C. WALsh. (Price Re. I; or Is.6d.).

III. The Exact Determination of the Fastness of the more Common Indigenous Dyes of Bengal, and comparison with typical synthetic Dye-stuffs. Part 1. Dyeing on Cotton.-By E. R. Watson. (Price Re. I ; or Is. 6d.)

IV. The Saorias of the Rajmahal Hills.-By R. B. BaInbridge. (Price Rs. 2; or 2s. 1od.)

V. Mundari Poetry, Music and Dances-By Rev. Fr. J. Hoffrann, S.J. (Price Re. I; or Is. $6 d$.)

VI. Tarikh-i-Nusvatjangi-By HaRINath DE. (Price Re. I ; or Is. 6d.)

VII. The Exact Determination of the Fastness of the more Common Indigenous Dyes of Bengal, and comparison with typical Synthetic Dye-stuffs. Part II. Dyeing on Silk. -By E. R. Watson. (Price Annas I 2; or I $s_{0} 2 d_{0}$ )

VIII. Monograph on Sea Snakes.-By MajoR F. Wali, I.M.S. (Price Rs. 5; or 7s.)

IX. A Polyglot List of Birds in Turki, Manchu and Chinese.-By E. Denison Ross,

PH.D. (Price Rs. 4 ; or $6 s_{\text {. }}$ ) [or $\cdot 1 s .6 d$.

X. Notes an some Monuments in Afghanistan.-By H. H. HAYden. (Price Re. I;

XI. On the Correlations of A reas of Matured Crops and the Rainfall, and certain allied prob. lems in Agriculture and Meteorology.-By S. M. JACOB, I.C.S. (Price Rs. 2-8; or $3 s_{0} 10 d_{\text {.) }}$ 


\section{Memoirs of the Asiatic Society of Bengal.}

Vol. 111.

I. Ramacarita by Sandhyakara Nandi.-Edited by MAHAMAHopadHyaya HaRAPRASAD SHASTRT, M.A. (Price Rs. 2 ; or $2 s$. Iod.)

II. An Alchemical Compilation of the I3th Century A.D.-By H. E. STAPLE'TON, B.A., B.Sc., and R. F. Azo. (Price Re. I; or Is. 6d.)

III. The Journals of Major Janes Rennell, F.R.S., First Surveyor-General of India.Edited by T. H. D. LATouche. (Price Rs. 4 ; or $6 s$. )

IV. Lisu Tribes of Burma-China Frontier.-By A. Rose and J. CogGrs Brown. (Price Rs. 3 ; or 45. )

V. The Vyavahâra-Mâtrikâ of Jimutavāhana.-By The Hon. Justice Sir AsuTosh MookerJeE, Saraswati, KT., C.S.I., M.A., D.I., D.Sc., F.R.A.S., F.R.S.E. (Price Re. I-8; or 2s. $3 d$.)

VI. Some Current Pushtu Folk Stories.-By F. H. MaLyon, 2Ist Punjabis. (Price Re. I- 8 ; or 2 s. $3 d$.)

VII. The Chank Bangle Industry.-By J. HORNEII. (Price Rs. 2; or 2s. 8d.)

VIII. Catuhisatikā by Arya Deva.-By Mahamahopadhyaya Haraprasad Shastri, C.I.E. (Price Rs. 2 ; or $2 s$. Iod.)

IX. Father A. Monserrate's Mongolicae Legationis Commentarius.-By REV. H. Hosten, S.J. (Price Rs. 4 ; or 5 s. 4 d.)

Vol. IV.

( $\left(u\right.$ course of publication concurrently with $\mathrm{V}_{\bullet}$ )

I. Sanskrit-Tibetan-English Vocabulary: being an edition and translation of the Mahãvyutpatti by AlEXANDER CSOMA DE KÖRÖS.-Edited by E. DENISON Ross, C.I.E., Ph.D., F.A.S.B., and Mahamahopadhyaya Satis Chandra Vidyabhusana, M.A., Ph.D., F.A.S.B. Part I. (Price Rs. 5 ; or 75. )

II. Ditto ditto Part II. (Price Rs. 5 ; or 75. )

Vol. $\mathrm{V}$.

I. Srid-pa-ho-a Tibeto-Chinese Tortoise Chart of Divination.-By MAHĀMAHOPĀDHyāya Dr. Satis ChandRa Vidyabhusana, M.A., Ph.D.; F.A.S.B. (Price As. 8 ; or Iod.)

II. Fragments of a Buddhist work in the ancient Aryan language of Chinese Furkistan.-Edited by STEN Konow. (Price Re. I-8; or 2s. 3d.)

III. The Pălas of Bengal.-By R. D. BANERJI. (Price Rs. 5 ; or 7s.)

Extra No, Abors and Galongs.-By GEORGE D-S-DunBar. (Price Rs.6; or 8s. 6d.)

Ditto Part III, ditto ditto (Price Rs. 2; or 2s. $8 d$.)

IV. Mirza Zu-l-Qarnain. A Christian Grandec of three Great Moghuls. With Notes on Akbar's Christian Wife and the Indian Bourbons.-By REv. H. HOSTEN, S.J. (Price Rs. $2-8$; or 35 . Iod.)

V. Miscellanca Ethnographica. PartIII. I. Wcighing Apparalus from the Southim Shan States.-By N. ANNANDALE, D.Sc., F.A.S.B. 2. The "Bismer" in Russia.-By DR. G. H. MEERWARTH. Note on the Elementary Mechanics of Balances and Steelyards.-By H. G. Graves. (Price Re. I-4; or Is. Iod.)

VI. A Revision of the Lizards of the Genus Tachydromus.-By G. A. BouLENGER, LI.D., D.SC., F.R.S. (Price Rs. 3 ; or $4 s .6 d$.)

Vol. VI.

(In course of publication concurvently with $V$. .)

I. Zoological Results of a Tour in the Far East.-Part I.-Polyzon Entoprocta and Ctenostomata.-By N. AnnandalE, D.Sc., F.A.S.B. (Zoological Survey of India). (Price Rs. 4 ; or 5 s. $4 d$.)

II. Zoological Results of a Tour in the Far East.-Part II.-Aquatic Hemiptera from the Tale Sap in Peninsular Siam.-By C. A. PAiva. Aquatic Oligochaeta from Japan and China.-By J. STEPHENSON, D.Sc. Hydrozoa and Ctenophora.By N. Annandale, D.Sc., F.A.S.B. Batrachia.-By N. ANNANdale, D.Sc., F.A.S.B.' (Price Rs. 5 ; or $7 s$.

III. Zoological Results of a Tour in the Far East._Part III._Himdinea.-By DR. Asajno Ora. Mollusca Nudibranchiata (Ascoglossa).-By/Sur CharLes EIIOT, M.A., K.C.M.G., C.B. (Price Re. I-8; or 2s. $3 d$.)

IV. Zoological Results of a Tour in the Far East.-Part IV.-Crustacea Decapoda and Stomatopoda.-By S. W. KEMP. (In press.) 




